\title{
Lise Öğrencilerinin Merak Düzeyleri İle Bilinçli Farkındalık Düzeyleri Arasındaki İlişkinin İncelenmesi
}

DOI: 10.26466/opus.919627

\author{
$*$ \\ Gürbüz Ocak* - Emine Akkas Baysal ${ }^{* *}$ - Ulviye Yer*** \\ * Prof. Dr., Afyon Kocatepe Üniversitesi, Eğitim Fakültesi, Afyonkarahisar/Türkiye \\ E-Posta: gocak@aku.edu.tr \\ ORCID: 0000-0001-8568-0364 \\ ** Dr.̈̈ğr. Üyesi, Afyon Kocatepe Üniversitesi, Sandıklı UBYO, Afyonkarahisar/Türkiye \\ E- Posta: akkasemine85@hotmail.com \\ ORCID: 0000-0002-5711-0847 \\ *** Öğretmen, Afyon Kocatepe Üniversitesi , Eğitim Fakültesi, Afyonkarahisar/Türkiye \\ E- Posta: ulviye.yer91@gmail.com \\ ORCID: 0000-0001-5647-7965
}

\section{Öz}

Bu araştırmanın amacı, lise öğrencilerinin cinsiyet, sınff, okul türü ve akademik başar değişkenlerine göre meraklllk düzeyleri ile bilinçli farkındalk düzeyleri arasındaki ilişkiyi incelemektir. Araştırma, tarama modelinde ilişkisel tarama olarak desenlenmiştir. Seçkisiz örnekleme türlerinden tabakal örnekleme yönteminin kullanıldığı bu araştırmaya 367 lise öğrencisi katılmıştır. Araştırmada Kashdan, Gallagher, Silvia, Winterstein, Breen, Terhar, ve Steger (2009) tarafindan geliştirilen ve Acun, Kapıkıran ve Kabasakal (2013) tarafindan Türkçe'ye uyarlanan "Merakllık Ölçeği" ile Brown ve Ryan (2003) tarafindan geliştirilen; Özyeşil, Arslan, Kesici ve Deniz (2011) tarafından Türkçe'ye uyarlan "Bilinçli Farkındalı Ölç̧ĕ̀i" kullamılmıştır. Demografik özellikler "Kişisel Bilgi Formu" ile toplanmıştır. Araştırma sonucunda, lise öğrencilerinin meraklllık düzeyleri ile bilinçli farknndalık düzeyleri arasında pozitif yönde zayıf bir ilişki olduğu belirlenmişstir. Kadınlarda negatif yönde zayıf ilişki tespit edilmiştir. Erkek öğrencilerde ise merakllık ölçeğinin kabullenme boyutunda pozitif yönde, zayıf bir ilişki olduğu görülmüştür. Yapılan araştırmada sinıf bazında anlaml iliş̧i sadece 11. smıflarda ve okul türü açısından görülï̈rken, pozitif yönde orta düzeye yakın bir ilişki bulunmuştur. Meraklllk eğilimi ile bilinçli farkındalık düzeyleri arasında Sosyal Bilimler Lisesi öğrencileri lehine anlaml farklllk olduğu sonucuna ulaşılmıştır. Bu durum Sosyal Bilimler Lisesi öğrencilerinin merak düzeyleri ve bilinçli farkındalık düzeylerinin, diğer okul türlerine göre pozitif yönde bir farklllk gösterdiğini ortaya çıarmaktadır. Sonuç olarak öğrencilerin merak düzeylerinin onlarm bilinçli farkındalı düzeylerini etkilediği söylenebilir.

Anahtar Kelimeler: Bilinçli Farkındalık, Merak, Lise Öğrencileri, Keşfetme. 


\title{
Examining the Relationship Between the Levels of Curiosity and Mindfulness of High School Students
}

\begin{abstract}
The aim of this study was to determine the relationship between the curiosity levels and mindfulness levels of high school students according to their gender, class, school type and academic achievement variables. The research was designed as relational scanning in the survey model. 367 high school students participated in this study, in which the stratified sampling method, one of the random sampling types, was used. The "Curiosity Scale" was developed by Kashdan, Gallagher, Silvia, Winterstein, Breen, Terhar, and Steger (2009) and adapted into Turkish by Acun, Kapıkıran and Kabasakal (2013), and by Brown and Ryan (2003); "Mindfulness Scale" was used, which was adapted into Turkish by Özyeşil, Arslan, Bıçak and Deniz (2011). Demographic features were collected with the "Personal Information Form". As a result of the research, it was determined that there was a positive weak relationship between the curiosity levels and mindfulness levels of high school students. There was a weak negative correlation in terms of women. In male students, it was observed that there was a positive and weak relationship in the acceptance dimension of the curiosity scale. In the research, while a meaningful relationship was found only in 11th grades and school type. It could be stated that there was a significant difference between the tendency for curiosity and mindfulness levels in favor of Social Sciences High School students. As a result, it can be said that the curiosity levels of students effect the mindfulness levels of high school students.
\end{abstract}

Key Words: Mindfulness, Curiosity, High School Students, Discovery. 


\section{Giriş}

İnsanoğlu hayatı boyunca etrafında gerçekleşen, nesne ve olayları merak ederek anlamlandırmaya çalışmıştır. Merak dürtüsü, insanlarda doğumdan ölüme kadar hiç tükenmeyen bir duygudur. Merak kavramı, Türk Dil Kurumu (2019) tarafından "Bir şeyi anlamak veya öğrenmek için duyulan istek" olarak tanımlanmaktadır. İngilizcede "meraklı (curious)" kelimesi Latince "dikkat" anlamina gelen cura'dan gelmektedir (A $\breve{g}$ ve Balc1, 2018). Almancada ise "yeniliğe aç / yeniye doymama" anlamina gelen "neu" ve "gierig" kelimelerinin birleşmesiyle (neugierig) meraklı kavramı oluşmuştur (Langenscheidt, 2019). Yani merak, bir bireyde bilinmeyeni öğrenmeye, anlamaya ve açılamaya dair oluşan ilgi, bilme ve anlama dürtüsüdür.

Eğitimde merak isteğinin, öğrenme faaliyetlerine büyük katkısı vardır. Merak insanların belirli bir alana, olaya ya da nesneye odaklanmasinı sağlar. Merak duygusu meslek seçiminde de rolü olan, bireye ait bir özelliktir (Holland, 1997; akt. Kaya, 2016). Bu nedenle, meslek seçimine yaklaşan lise öğrencilerinin merak düzeyleri, onların akademik başarılarını ve mesleki kariyerlerini etkilemektedir. Özellikle okuma parçalarına yönelik merak ve ilgi; soyut kavramların anlaşılmasını, anlamın kolayca kavranmasını ve bireylerde hızlı odaklanmayı sağlamaktadır. Eğitimde ve sosyal hayatta bir alana karşı duyulan ilgi ve merak çok önemlidir. Çünkü merak dürtüsü o alanda üst düzey becerisi olmayan öğrencilerin dâhi, gayret ederek gelişmesini hatta o alanda pratikleşmesini sağlar. Bireyleri keşfetmeye yönelterek bu yöndeki çabalarını sürdürmelerini sağlayan merak, her birey için olumlu bir duygudur. Eğitimde, merak ve güdünün sağlanmasının öğrenmeyi ve performansı beraberinde getireceği yönündeki görüşleri 1913 yılında ilk dile getiren kişilerden biri Dewey'dir (Soydan, 2013). Ona göre meraklı bir öğrenci, zihin haritasına yeni şemalar ekleyerek yeni öğrenmeleri kolaylaştırırken, merak düzeyi düşük olan bir öğrenci zihninde çok fazla yeni şemalar oluşturamadığ 1 için öğrenme nitelikli olmayacaktır. Merak duygusunun ilgiyi beraberinde getirmesi, merak düzeyi yüksek olan bir bireyin dikkat ve odaklanma konusunda ilgi duyduğu alanda daha başarılı olacağını gösterir.

Bilinçli farkındalık, dikkatin o anda yapılana odaklanıp, gerçekleştirilen eylemin farkında olmak demektir. Bilinçli farkındalık, dikkat düzen- 
leme, kendini tanıma ve duygusal düzenleme arasında sinerjik bir çaba ile işlev görür (Langer ve diğerleri, 2017). Yani bireyin dikkatini odaklama, kendini tanıma ve duygu durumlarının farkında olabilmesidir. Ayrıca yaşanılan olaylarda olumlu veya olumsuz diye herhangi bir yarg1lamaya varmadan, gerçekleşen durumun farkında olma halidir. Brown ve Ryan (2003), bilinçli farkındalığın zıddı olan, umursamazlık (mindlessness) durumunun, bir düşünceyi, duyguyu, niyeti kabul etmek veya onunla ilgilenmeyi reddetmek olduğunu belirtmiştir. Bu durum bilinçli farkındalığı düşük olan bireylerin ânı yaşamasından, vuku bulan olaylara tam odaklanamamasından, ilgili durumlara ya da nesnelere merak duymamasından kaynaklı olabilir.

Duygu, düşünce ve tecrübelerin, bilgi birikimine dönüşmesinde merak dürtüsü bireylerde ilgi, dikkat ve konsantrasyonu oluşturmaktadır. Birey ilgisi olan konuyu daha detaylı inceleyip; merak, keşfetme ve özümseme basamaklarıyla kalıcı öğrenmeyi gerçekleştirir. Bireylerde oluşan merak dürtüsü, odaklanmayı artırmaktadır. Çocuğun sağlıklı bir birey olarak gelişiminde 0-18 yaş arasının hassas dönemler olduğunu kabul eden Montessori, eğitimde dikkatin yoğunlaştırılmasına önem vermiştir (Arslan, 2008). Eğitim felsefesini oluştururken öğrencilerinin merak duygusunu dikkate alan Montessori, sınıfındaki her çocuğun materyal seçerken merak ettiği konuları dikkate aldığını, eğitimin ilk ve önemli amacının, çocuğun kendisini keşfetmesi ve özgürleştirilmesi olduğunu belirtmiştir. 0-18 yaş arasının hassas dönemler olduğunu kabul eden Montessori, en iyi öğrenmenin ilgi ve merakın olduğu durumlarda ortaya çıktığını savunmaktadır (Ludwig, 2015). Bu doğrultuda, bilinçli farkındalık düzeyi yüksek olan bir öğrencinin, merak duygusunun da yüksek olması muhtemeldir. Bilinçli farkındalıkta dikkati hem içsel hem dişsal alanda tutmak önemlidir (Şahin, 2019). Bu durum ise merak duygusunu ön koşul haline getirmektedir. Alan yazın incelendiğinde bilinçli farkındalık çoğunlukla psikolojik temalarla ilişkilendirilmiş (Arslan, 2018; Demir, 2017; Şahin, 2019; Ülev, 2014) ancak merak ile ilişkisini inceleyen bir araştırmaya rastlanılmamıştır. Öğrencinin ilgi, motivasyon, dikkat ve merak duygularının eğitimde önemli halkalar olduğu yadsınamaz bir gerçektir. Bu halkaların birbiriyle ilişkisi ne kadar sağlam olursa, öğrenme de o kadar kalıcı olur. Bu nedenle yapılan araştırma 1318 yaş aralığında olan lise öğrencilerinin merak ve keşfetme düzeylerinin 
bilinçli farkındalık düzeylerine etkisinin belirlenmesi eğitim açısından önemli rol oynamaktadır.

Birbirleriyle ilişkili olan merak ve öğrenme olgusu yaşam boyu bireyi olumlu etkilemektedir. Kişinin merak ettiği konular, dönemsel gelişim alanlarına göre çocukluktan yetişkinliğe kadar değişse de merak dürtüsü her zaman sürmektedir. Eğitimde merak konusu öğrenmenin önkoşuludur. Lise öğrencilerinde merak, ergenlik döneminde meslek seçimlerine kadar bireyi etkilemektedir. Öğrencinin bir alanda merak duymasının yanı sıra, kendini ve duygularını düzenleyebilmesi ergenlik döneminde dikkat edilmesi gereken bir konudur. Bu durumda bilinçli farkındalık kavramı ön plana çıkmaktadır. Lise öğrencilerinin merak ve bilinçli farkındalık düzeyleri, yaş, cinsiyet, sınıf ve akademik başarıları ile ne düzeyde ilişkili olduğu eğitim bağlamında bu açıdan önem arz etmektedir.

Araştıran, keşfeden, özgüveni yüksek olan, bilimsel düşünen ve doğru kararlar verebilen bireyler yetişmesini sağlamak, merak duygusunu eğitim sistemimizde kullanarak mümkün olabilir. Özyeşil (2011) bilinçli farkındalığın bireylere yalın dikkat tutumunu, kendini tanımayı ve duyusal-zihinsel farkındalığı sağladığını belirtmiştir. Duyusal-zihinsel farkındalık, merak duygusuyla ve odaklanma ile mümkündür. Aynı zamanda bilinçli farkındalığın depresyon ve stres düzeyi (Demir, 2014) üzerinde etkili olduğu görülmektedir. Eğitimin bütünsel bir gelişim sürecini göz önüne alırsak, öğrencinin zihinsel, duygusal, öznel iyi oluş durumları merak dürtüsüyle birleştiğinde kalıcı ve üretici öğrenmelerin gerçekleşmesi söz konusudur.

Merak ve keşfetme dürtüsünün yüksek olması bireyde kalıcı öğrenmeyi sağlamanın yanı sıra düşünme becerilerinin gelişmesine, yaratıcı, üretken, araştıran bireyler olarak yetişmesine katkı sağladığı görülmektedir (Çelik ve Topçuoğlu, 2017). Darancık (2018), motivasyonun alt yapısı olan merak duygusunun yabancı dil öğretimindeki etkisini araştırmış ve öğrencinin merak duygusuyla birlikte hem eylemde hem de üretimde bulunduğunu belirtmiştir. Özer ve Korkmaz (2016) merak duygusunun yabancı dil öğretiminde öğrencinin başarısını etkileyen unsurlardan biri olduğunu, İnan Kaya (2016) merakın keşif davranışı üzerindeki öncüllüğünün önemini belirtmiştir. Bu durum merak duygusunun kişinin bulunduğu "ân"a odaklanmasındaki etkisini ve dolaylısıyla bireydeki üretme becerisinin geliştirdiğini göstermektedir. Bu nedenle 
merak dürtüsü, bilinçli farkındalık belirten dikkat, bulunduğu anın farkında olma, kendini tanıma ve anlamlandırma durumlarıyla ilişkili olması mümkündür.

Karabacak ve Demir (2017) ise kökeni Budizm'e dayanan bilinçli farkındalık terimini, herhangi bir yargılama yapmadan sadece şu anda olan durumlara odaklanma olarak belirtir. Bu bağlamda eylemin içeriğinden ziyade sürdürülebilir dikkat süreci önemlidir. Çatak ve Ögel (2010) farkındalık uygulamaları ile bilişsel-davranışçı terapilerin, üst biliş, duygu düzenleme, dikkat düzenleme konusunda benzer bir yapılanmaya sahip olduğunu belirtmektedir. O halde bilinçli farkındalığı yüksek olan bireyler kendi zihinsel hareketlerinin bilincindedirler ve belli bir noktaya odaklanma ve dikkatlerini yoğunlaştırma konusunda da başarılıdırlar. Belirli bir konuya odaklanma ve o alana yoğunlaşmayı sürdürebilme merak duygusu ile beslenmektedir. Bu nedenle bir alana merak duyan bireyler, o alana daha fazla odaklanabilmekte ve dikkatlerini merak ettiği şeyler üzerinde yoğunlaştırabilmektedir.

Öğrenmenin ilgi çekici değilse bilinçsizlik/umursamazlık olacağını savunan Langer (1993) eğitim sürecinin eğlenceli oldukça bilinç seviyesinin artacağını ve öğrencilerin daha çok öğrenebileceğini savunur. Yani eğitimde merak ve keşfetme dürtüleri, öğrencinin bulunduğu "ân"a odaklanmasını sağlaması sebebiyle, bilinçli farkındalığı arttırmak için önemli etkenler arasındadır. Aynı şekilde Baysal ve Demirbaş (2012) bilinçli farkındalığın; beyin, vücut, beceri, yaratıcılık, dikkat, öğrenme ve yaşam kalitesi üzerinde etkisinin olumlu olduğunu belirtmiştir. Psikolojik bir süreç olarak da kullanılan bilinçli farkındalık sadece bilişsel becerileri değil aynı zamanda duyuşsal becerileri de doğrudan etkilemektedir (Germer, Siegel ve Fulton, 2005). Bilinçli farkındalığ 1 yüksek olan birey, içinde bulunduğu olaylara hakim olup, yargılamaya gitmeden duygu ve davranışlarını düzenleyebilmektedir. Bilinçli farkındalığın önemli basamaklarından birincisi dikkatin öz-düzenlenmesi (kendinden ayarlanması), ikincisi ise anlık deneyim sırasında yaşanan merak, kabullenme ve açık olma kavramlarının oryantasyonudur (Bishop, 2004). Bireyin dikkatini bilerek ve isteyerek yönlendirmesi, dikkati ve farkındalığ 1 merak ile sürdürüp, kabullenici bir şekilde şu andaki deneyimlere yönlendirmektir. Bu da anı tam anlamıla yaşamaya niyet etmeyi göstermektedir (Özyeşil, 2011). Yani dikkatini bilinçli bir şekilde düzenleyebi- 
len bir birey, eğitimde neyi, nasıl ve ne şekilde öğreneceğinin bilincinde olur. Bu sebeple, lise öğrencilerinin merak ve bilinçli farkındalık düzeyleri arasındaki ilişkinin cinsiyet, akademik başarı, farklı okul türleri ve sinıfları açısından incelenmesi öğrencinin farkındalığını arttırılmasına yönelik öğretimde yeni teknik ve yöntemlerin geliştirilmesine katkı sağlayacağı öngörülmektedir. Öğrencilerde odaklanma, öz düzenleme, meraklılık ve keşfetme özellikleri üzerine elde edilen veriler eğitimde ve psikolojide yeni metotların geliştirilmesine ve bunların kullanılmasına dair yol gösterici olacağı düşünülmektedir. Bu bağlamda, araştırmanın amacı Afyonkarahisar (merkez) ilindeki lise öğrencilerinin bazı demografik özelliklere göre merak ve keşfetme düzeyleri ile bilinçli farkındalık düzeyleri arasındaki ilişkiyi incelemektir. Bu çerçevede aşağıdaki sorulara cevap aranacaktır:

1. Lise öğrencilerinin merak ve keşfetme düzeyleri ile bilinçli farkındalık düzeyleri arasındaki anlamlı bir ilişki var mıdır?

2. Lise öğrencilerinin merak ve keşfetme düzeylerinin dağılımları nasıldır?

3. Lise öğrencilerinin bilinçli farkındalık düzeylerinin dağılımı nasıldir?

4. Lise öğrencilerinin merak ve keşfetme düzeyleri ile bilinçli farkındalık düzeyleri arasında cinsiyet değişkenine göre anlamlı bir ilişki var mıdır?

5. Lise öğrencilerinin merak ve keşfetme düzeyleri ile bilinçli farkındalık düzeyleri arasında sınıf değişkenine göre anlamlı bir ilişki var midır?

6. Lise öğrencilerinin merak ve keşfetme düzeyleri ile bilinçli farkındalık düzeyleri arasında okul değişkenine göre anlamlı bir ilişki var midır?

7. Lise öğrencilerinin merak ve keşfetme düzeyleri ile bilinçli farkındalık düzeyleri arasında akademik başarı (yılsonu ortalamasına) göre anlamlı bir ilişki var mıdır?

8. Lise öğrencilerinin merak düzeylerinde, bilinçli farkındalık düzeyleri ve cinsiyetin ortak etkisine bağlı olarak anlamlı bir farklılık var midir? 
9. Lise öğrencilerinin merak düzeylerinde, bilinçli farkındalık düzeyleri ve okul türünün ortak etkisine bağlı olarak anlamlı bir farklılık var midir?

10. Lise öğrencilerinin merak düzeyleri, bilinçli farkındalık düzeyleri ve akademik başarılarının (yılsonu ortalamasına) ortak etkisine bağlı olarak anlamlı bir farklılık göstermekte midir?

\section{Yöntem}

\section{Model}

$\mathrm{Bu}$ araştırma nicel araştırma yöntemlerinden ilişkisel tarama modeli kullanılarak yapılmıştır. İlişkisel tarama modeli, iki ve daha fazla sayıdaki değişken arasında birlikte değişim varlığını veya derecesini belirlemeyi amaçlayan araştırma modelidir (Karasar, 2009). Bu modelde elde edilen ilişkiler gerçek bir neden-sonuç ilişkisini belirtmez; ancak, bu açıdan bazı ipuçları vermesi mümkündür. Bu araştırmada Afyonkarahisar merkez lise öğrencilerinin merak ve keşfetme düzeyleri ile bilinçli farkındalık düzeyleri arasındaki ilişki çeşitli değişkenler açısından ele alınacaktır. Bu sebeple ilişkisel tarama modeli ile desenlenmiştir.

\section{Evren ve Örneklem}

Araştırma 2019-2020 eğitim-öğretim yılının ilk döneminde Afyonkarahisar ili merkez lise öğrencileri ile yürütülmüştür. Araştırmanın örneklemini belirlemek için basit seçkisiz örnekleme yöntemlerinden biri olan tabakalı örnekleme yöntemi kullanılmıştır. Tabakalı örnekleme, evrendeki özel kriterlere göre ayrılan tabakalar belirlenip bunların evrende var oldukları aynı oranlarıyla örneklerinde temsil edilmelerini sağlayan bir örneklem seçme tekniğidir (Şahin ve Karakuş, 2019). Öncelikle çalışma evreni okul türü bazında 3 tabakaya ayrılmıştır. Araştırmanın örneklemini Mesleki ve Teknik Anadolu Lisesi (123), Anadolu Lisesi (105) ve Sosyal Bilimler Lisesi'nde (139) öğrenim gören 367 lise öğrencisi oluşturmaktadır. Yazıcıoğlu ve Erdoğan (2004; akt. Hocaoğlu ve Baysal, 2019)'a göre 25000 kişilik bir evrende \% 95 güven aralığ1 ve \% 3 sapma miktarı için toplam 319 kişilik örneklem yeterlidir. Bu çalışmada 157 
kadın ve 210 erkek öğrenci olmak üzere toplam 367 öğrenciden veri toplanmıştır.

\section{Veri Toplama Araçları}

Merak ve Keşfetme Ölçeği II (MKÖ): Araştırmada, Kashdan, Gallagher, Silvia, Winterstein, Breen, Terhar, ve Steger (2009) tarafından geliştirilen, Türkçe uyarlaması Kapıkıran ve Kabasakal (2013) tarafından yapılan Merak ve Keşfetme Ölçeği II (MKÖ) kullanılmıştır. Ölçek, "esneklik” ve "belirsizliği kabul etme" alt boyutlarından ve 5'li likert türünde toplam 10 maddeden oluşmaktadır. Veriler için hem açımlayıcı hem de doğrulayıcı faktör analizi yapılmıştır. Doğrulayıcı Faktör Analizi (DFA) sonuçları bu alt boyutların birbiriyle yüksek düzeyde ilişkili olduğunu göstermiştir ( $\mathrm{r}=.85)$. Ölçekten alınabilecek minimum puan (10x1) 10, ortanca puanı (10x3) 30 ve maksimum puan (10x5) 50 puandır. Ölçek maddelerinin toplamında elde edilecek yüksek puan yüksek merakı ifade etmektedir. Ölçeğin Türkçe ve İngilizce formlar arasındaki korelasyon katsay1larının .65 ile .86 arasında sıralanmaktadır. Ölçeğin Cronbach Alfa güvenirlik katsayısı, ölçeğin tüm maddeleri için .82, esneklik alt ölçeği için .81 ve belirsizliği kabul etme alt ölçeği için .67 olduğu belirlenmiştir.

Bilinçli Farkındalık Ölçeği (BİFÖ): Brown ve Ryan (2003) tarafından geliştirilen Bilinçli Farkındalık Ölçeği (BİFÖ), günlük yaşamın farkında olma ve bunlara karşı dikkatli olma yönündeki genel eğilimi ölçen 15 maddelik bir ölçektir. Bu ölçekten alınabilecek minimum puan (15x1) 15, ortanca puanı (15x3) 45 ve maksimum puan (15x5) 75 puan olarak belirlenmiştir. BİF̈'den elde edilen yüksek puan bilinçli farkındalığın yüksek olduğunu gösterir. Tek boyutlu olan ölçek Özyeşil, Arslan, Kesici ve Deniz tarafından Türkçe'ye uyarlanmıştır. Orijinal ölçeğin iç tutarlık katsayısı .82 ve test tekrar-test güvenirliği .81 olarak bulunmuştur (Brown ve Ryan, 2003). Ölçeğin Cronbach Alpha iç tutarlılık katsayısı. 80 ve test-tekrar test korelasyon .86 olarak hesaplanmıştır.(Özyeşil ve diğerleri, 2011). BİFÖ "hemen hemen her zaman, çoğu zaman, bazen, nadiren, oldukça seyrek, hemen hemen hiçbir zaman" şeklinde 6'll Likert tipi bir ölçektir. Bu tür ölçme araçlarında yanıtlayıcı, ölçekteki her maddenin anlamına ilişkin tutumunun derecesini belirtir (Tezbaşaran,1997; Sekreter 
ve Akyüz, 2003, s.128). Yapılan araştırmada puanlayıcı güvenirliği aç1sindan ve "nadiren ve oldukça seyrek" derecelendirmesi puanlayıcılar tarafından benzer anlam ifade ettiği için veriler 5'li Likert şeklinde toplanmıştır. Oluşturulan ölçme aracında öğrencilerin demografik özellikleri, meraklılık ve bilinçli farkındalık düzeylerine ilişkin maddeler bulunmaktadır. Ölçeklerde, ters puanlanan madde bulunmamaktadır. Yapılan araştırmanın ölçek derecelerine dair aralıkları aşağıda Tablo 1'de verilmiştir:

Tablo 1. 5'li Derecelendirme Ölçeği Puan Aralı̆̆ı

\begin{tabular}{|c|c|c|}
\hline Seçenekler & Verilen Puanlar & Puan Aralığı \\
\hline Hiç Katıliyorum & 1 & $1-1.80$ \\
\hline Katılmıyorum & 2 & $1.81-2.60$ \\
\hline Ne Katıliyorum Ne Katılmıyorum & 3 & $2.61-3.40$ \\
\hline Katıliyorum & 4 & $3.41-4.20$ \\
\hline Tamamen Katıliyorum & 5 & $4.21-5.00$ \\
\hline
\end{tabular}

\section{Verilerin Analizi}

Analiz aşamasında ilk olarak hangi istatistiksel testlerin yapılacağını belirlemek adına verilerin normal dağılıp dağılmadığı tespit edilmiştir. Araştırmada "Meraklılık Ölçeğinin" tamamının ve alt boyutlarının eğrilik ve basıklık değerlerinin +1 ile -1 değerlerinin arasında olduğu belirlenmiştir. Bu nedenle elde edilen değerlerin normal dağılım gösterdiği kabul edilebilir (Tabachnick ve Fiedell, 2013, akt. Boyraz ve Tepe, 2019). "Bilinçli Farkındalık Ölçeğinin" de yapılan istatistik işlemleri sonucunda $\mathrm{p}=, 085$ olduğu belirlenmiştir. Bu sonuç BİFÖ'nün normal dağıldığ1 göstermektedir $(p>, 050)$. Veriler normal dağılım gösterdiği için betimsel istatistikler, parametrik testlerden varyans analizi uygulanmıştır. Varyans analizinde görülen farklılığın hangi gruplardan kaynaklandığını ortaya koymak için Scheffe testi de yapılmıştır. Ayrıca meraklılık ve keşfetme düzeyleri ile bilinçli farkındalık düzeyleri arasındaki ilişkinin incelenmesinde korelasyon analizi yapılmıştır. Analiz sonuçları 0.05 anlaml1lık düzeyinde değerlendirilmiştir. Meraklılık ve bilinçli farkındalık ölçeği arasındaki ilişkiyi incelemek için korelasyon analizi yapılmıştır. 


\section{Bulgular}

Lise öğrencilerinin meraklılık ve bilinçli farkındalık düzeylerinin incelendiği bu araştırmada Anadolu Lisesi, Sosyal Bilimler Lisesi ve Mesleki ve Teknik Anadolu Lisesi öğrencilerinden elde edilen istatiksel sonuçlar, araştırmanın alt problemleri bağlamında aşağıda sırasıyla sunulmuştur.

\section{Lise öğrencilerinin merak ve keşfetme düzeylerinin dağılımları nasıl- dir?}

Araştırmanın birinci alt problemi olan "Lise öğrencilerinin merak ve keşfetme düzeylerinin dağılımları nasıldır?" sorusunu yanıtlamak için yapılan analiz sonuçları Tablo 2'de yer almaktadır.

Tablo 2. Lise Öğrencilerin Meraklılık Düzeylerine İlişkin Betimsel İstatistikler

\begin{tabular}{lllllc}
\hline & N & Min. & Max. & X & Ss \\
\hline Esneklik boyutu & 340 & 9,00 & 30,00 & 30,00 & 3,78 \\
Kabullenme boyutu & 340 & 4,00 & 20,00 & 12,60 & 2,76 \\
Meraklllik Toplam Puanı & 340 & 13,00 & 49,00 & 33,27 & 5,55 \\
\hline
\end{tabular}

Ölçekten alınan puanlar analiz edildiğinde, alınan en düşük puanın 13, en yüksek puanın 49 olduğu Tablo 2' de görülmektedir. Alınan sonuçlarda lise öğrencilerinin merakl1lık düzeylerinden elde ettikleri ortalamanın $(X=33,27)$ ölçek orta puanından yüksek olduğu görülmektedir. Beklenen orta puanın (10x3) 30 olmasına kıyasla, bu durum lise öğrencilerinin meraklılık düzeylerinin yüksek olduğunu belirtilebilir. Lise öğrencilerinin meraklılık düzeyinin 6 maddeyi kapsayan $(6 \times 3=18)$ esneklik alt boyutuna ilişkin puan ortalamasının 20,66; 4 maddeden oluşan (4x3=12) belirsizliği kabullenme alt boyutu ortalamasının ise 12,60 olduğu görülmektedir. Ölçeğin iki alt boyutunun ortalamaları orta değerin üzerindedir. Buna göre lise öğrencilerinde merak oluşturan ilgi alanlarının çeşitlendiğini, tek bir konudan ziyade ilgi duydukları, dikkat ettikleri ve merak ettikleri her konuya yoğunlaşabilecekleri düşünülmektedir. Lise öğrencilerinin ölçekteki maddeleri hangi düzeyde gösterdiğini belirlemek amacıyla öğrencilerin her bir maddeye verdikleri cevapların ortalamaları alınmış ve bulunan ortalamalar karşılık geldikleri düzey ile birlikte Tablo 3'te ifade edilmiştir. 
Tablo 3. Meraklılık ve Keşfetme II Ölçeğinin Frekans, Yüzde ve Madde Ortalamaları

\begin{tabular}{|c|c|c|c|c|c|c|c|c|}
\hline Madde & $\begin{array}{l}\mathrm{f} \\
\%\end{array}$ & 1 & 2 & 3 & 4 & 5 & $x$ & Düzey \\
\hline \multirow{2}{*}{$\begin{array}{l}\text { 1.Yeni durumlarda aktif } \\
\text { olarak edinebildiğim kadar } \\
\text { bilgi ararım. }\end{array}$} & $\mathrm{f}$ & 13 & 27 & 90 & 155 & 55 & 3,62 & $\mathrm{~K}$. \\
\hline & $\%$ & 3,8 & 7,9 & 26,5 & 45,6 & 16,2 & & \\
\hline \multirow{2}{*}{$\begin{array}{l}\text { 2.Günlük yaşamın belirsiz- } \\
\text { liğinden gerçekten hoşla- } \\
\text { nan bir insanımdır. }\end{array}$} & $\mathrm{f}$ & 81 & 80 & 90 & 54 & 35 & 2,65 & N.K \\
\hline & $\%$ & 23,8 & 23,5 & 26,5 & 15,9 & 10,3 & & \\
\hline \multirow{2}{*}{$\begin{array}{l}\text { 3.Karmaşık ya da mücade- } \\
\text { le gerektiren şeyler yap- } \\
\text { mada çok iyiyimdir. }\end{array}$} & $\mathrm{f}$ & 25 & 35 & 89 & 116 & 75 & 3,53 & K. \\
\hline & $\%$ & 7,4 & 10,3 & 26,2 & 34,1 & 22,1 & & \\
\hline \multirow{2}{*}{$\begin{array}{l}\text { 4.Gittiğim her yerde yeni } \\
\text { şeyler ya da deneyimler } \\
\text { ararım. }\end{array}$} & $\mathrm{f}$ & 12 & 25 & 67 & 143 & 93 & 3,82 & $\mathrm{~K}$. \\
\hline & $\%$ & 3,5 & 7,4 & 19,7 & 42,1 & 27,4 & & \\
\hline \multirow{2}{*}{$\begin{array}{l}\text { 5.Mücadele edilmesi } \\
\text { gereken durumları gelişme } \\
\text { ve öğrenme fırsatı olarak } \\
\text { görürüm }\end{array}$} & $\mathrm{f}$ & 18 & 36 & 85 & 129 & 72 & 3,59 & $\mathrm{~K}$. \\
\hline & $\%$ & 5,3 & 10,6 & 25,0 & 37,9 & 21,2 & & \\
\hline \multirow{2}{*}{$\begin{array}{l}\text { 6.Biraz korkutucu olan } \\
\text { şeyleri yapmaktan hoşlanı- } \\
\text { rım. }\end{array}$} & $\mathrm{f}$ & 39 & 37 & 83 & 97 & 84 & 3,44 & $\mathrm{~K}$. \\
\hline & $\%$ & 11,5 & 10,9 & 24,4 & 28,5 & 24,7 & & \\
\hline \multirow{2}{*}{$\begin{array}{l}\text { 7.Daima kendime ve } \\
\text { dünyaya ilişkin olabilecek } \\
\text { güçlüklerle ilişkili dene- } \\
\text { yimler ararım. }\end{array}$} & $\mathrm{f}$ & 13 & 51 & 134 & 108 & 34 & 3,29 & N.K \\
\hline & $\%$ & 3,8 & 15,0 & 39,4 & 31,8 & 10,0 & & \\
\hline \multirow{2}{*}{$\begin{array}{l}\text { 8. Kesinlikle kestirilemeyen } \\
\text { - tahmin edilemeyen işleri } \\
\text { tercih ederim. }\end{array}$} & $\mathrm{f}$ & 56 & 80 & 104 & 64 & 36 & 2,83 & N.K \\
\hline & $\%$ & 16,5 & 23,5 & 30,6 & 18,8 & 10,6 & & \\
\hline \multirow{2}{*}{$\begin{array}{l}\text { 9. Kişi olarak gelişebilece- } \\
\text { ğim ve kendimle mücadele } \\
\text { edebileceğim deneyimler } \\
\text { ararım. }\end{array}$} & $\mathrm{f}$ & 8 & 36 & 91 & 131 & 74 & 3,66 & $\mathrm{~K}$. \\
\hline & $\%$ & 2,4 & 10,6 & 26,8 & 38,5 & 21,8 & & \\
\hline \multirow{2}{*}{$\begin{array}{l}\text { 10. Aşina olmadığım } \\
\text { kişileri, olayları ve yerleri } \\
\text { kabul eden bir insanımdır. }\end{array}$} & $\mathrm{f}$ & 79 & 55 & 92 & 78 & 36 & 2,81 & N.K \\
\hline & $\%$ & 23,2 & 16,2 & 27,1 & 22,9 & 10,6 & & \\
\hline
\end{tabular}

(K. :Katılıyorum; N.K. : Ne Katılıyorum Ne Katılmıyorum)

Tablo 3'te belirtildiği gibi ölçeğin esneklik boyutunu yansıtan ve yüksek ortalamaya sahip maddelere örnek olarak şunlar verilebilir:

"M4: Gittiğim her yerde yeni şeyler ya da deneyimler ararım ( $X=3,82)$; M9: Kişi olarak gelişebileceğim ve kendimle mücadele edebileceğim firsatları sıklıkla ararım $(X=3,66)$; M1: Yeni durumlarda aktif olarak edinebildiğim kadar bilgi ararım $(X=3,62)$ ". Çalışmaya katılan öğrenciler ölçekteki maddelerin büyük kısmını "Katıllyorum" diye belirtmişlerdir. Tablo 3'e göre ölçeğin belirsizliği kabul etme boyutunu yansıtan ve yüksek ortalamaya sahip maddelere örnek olarak şunlar verilebilir: "M6: Biraz korkutucu olan şeyle- 
ri yapmaktan hoşlanırım ( $X=3,44)$; M8: "Kesinlikle kestirilemeyen - tahmin edilemeyen işleri tercih ederim. $(X=2,83)$ ". Tablo 3'te görüldüğü gibi, çalışmaya katılan öğrencilerin ölçekteki maddelerin büyük kısmını "Ne Katılıyorum Ne Katılmıyorum" olarak belirtmişlerdir.

Ölçeğe verilen cevaplar incelendiğinde, belirsizliği kabul etme boyutunu yansitan maddelere kıyasla öğrencilerin, esneklik boyutundaki maddelere daha yüksek düzeyde katılım gösterdikleri görülmektedir. Öğrencilerin alışılmışın dişında bir deneyim tercih etmedikleri, kendilerini çok yormayan, daha az zaman ve çaba isteyen şeyleri tercih ettikleri düşünülebilir. Ancak bu olgunun öğrencilerin çevrelerindeki sosyal aktivitelere ulaşabilme ve bu etkinliklerden yararlanma olanakları açısından da düşünülmesi gerekebilir. Çevrenin, ailenin, sosyal medyanın ve yetiştirilme koşullarının da etki edebileceği belirtilebilir. Sonuç olarak öğrencilerin merak ettikleri konu alanlarının değişebileceği, yeniliklere ve öğrenmeye karşı olumlu oldukları, ancak öğrencilerin rutin, ayrıntı isteyen ve sebat gerektiren konulara öğrenme isteği duymadıkları söylenebilir.

\section{Lise Öğrencilerinin Bilinçli Farkındalık Düzeylerinin Dağılımı Nasıl- dir?}

Araştırmanın ikinci alt problemi "Lise öğrencilerinin bilinçli farkındalık düzeylerinin dağılımı nasıldır?" sorusuna cevap vermek amacıyla maddelerin frekans, yüzde ve ortalamaları incelenmiştir. Bilinçli Farkındalık ölçeğin dair betimsel istatistikler olarak tek boyutlu ölçekte ortalamanın $(X=40,84)$ düşük olduğu görülmektedir. Ölçek 5'li likert tipinde uygulanmasından dolayı alınabilecek en düşük puan (15x1) 15, orta puan (15x3) 45 ve yüksek puan da (15x5) 75 olduğu görülmektedir. Yapılan frekans analizinde ölçekten alınan en düşük puanın 18 ve en yüksek alınan puanın 70 olduğu görülmektedir. Bu durum lise öğrencilerinin bilinçli farkındalık düzeylerinin ortalamanın altında olduğunu göstermektedir. 
Tablo 4. Bilinçli Farkındalık maddelerinin Frekans, Yüzde ve Madde Ortalamalarn

\begin{tabular}{|c|c|c|c|c|c|c|c|c|}
\hline Madde & $\begin{array}{r}\mathrm{f} \\
\%\end{array}$ & 1 & 2 & 3 & 4 & 5 & $x$ & Düzey \\
\hline $\begin{array}{l}\text { 1. Belli bir süre farkında olmadan bazı } \\
\text { duyguları yaşayabilirim. }\end{array}$ & $\begin{array}{r}\mathrm{f} \\
\%\end{array}$ & $\begin{array}{l}37 \\
10,1\end{array}$ & $\begin{array}{ll}53 \\
14,4\end{array}$ & $\begin{array}{l}65 \\
17,7\end{array}$ & $\begin{array}{l}129 \\
35,1\end{array}$ & $\begin{array}{l}83 \\
22,6\end{array}$ & 3,45 & NK \\
\hline $\begin{array}{l}\text { 2. Eşyaları özensizlik, dikkat etmeme } \\
\text { veya başka bir şeyleri düşündüğüm } \\
\text { için kırarım veya dökerim. }\end{array}$ & $\begin{array}{r}\mathrm{f} \\
\%\end{array}$ & $\begin{array}{l}112 \\
30,5\end{array}$ & $\begin{array}{l}99 \\
27,0\end{array}$ & $\begin{array}{l}63 \\
17,2\end{array}$ & $\begin{array}{l}62 \\
16,9\end{array}$ & $\begin{array}{l}31 \\
8,4\end{array}$ & 2,45 & $\mathrm{KM}$ \\
\hline $\begin{array}{l}\text { 3. Şu anda olana odaklanmakta zorla- } \\
\text { nırım. }\end{array}$ & $\begin{array}{r}\mathrm{f} \\
\% \\
\end{array}$ & $\begin{array}{l}62 \\
16,9 \\
\end{array}$ & $\begin{array}{l}72 \\
19,6 \\
\end{array}$ & $\begin{array}{l}109 \\
29,7\end{array}$ & $\begin{array}{l}92 \\
25,1 \\
\end{array}$ & $\begin{array}{l}32 \\
8,7 \\
\end{array}$ & 2,89 & NK \\
\hline $\begin{array}{l}\text { 4. Gideceğim yere, yolda olup bitenle- } \\
\text { re dikkat etmeksizin hızlıca yürüyerek } \\
\text { gitmeyi tercih ederim. }\end{array}$ & $\begin{array}{r}\mathrm{f} \\
\%\end{array}$ & $\begin{array}{l}74 \\
20,2\end{array}$ & $\begin{array}{l}96 \\
26,2\end{array}$ & $\begin{array}{l}95 \\
25,9\end{array}$ & $\begin{array}{l}65 \\
17,7\end{array}$ & $\begin{array}{l}37 \\
10,1\end{array}$ & 2,71 & NK \\
\hline $\begin{array}{l}\text { 5. Fiziksel gerginlik ya da rahatsızlık } \\
\text { içeren duyguları, gerçekten dikkatimi } \\
\text { çekene kadar fark etmeme eğilimim } \\
\text { vardır. }\end{array}$ & $\begin{array}{r}\mathrm{f} \\
\%\end{array}$ & $\begin{array}{l}84 \\
22,9\end{array}$ & $\begin{array}{l}94 \\
25,9\end{array}$ & $\begin{array}{l}86 \\
23,4\end{array}$ & $\begin{array}{l}71 \\
19,3\end{array}$ & $\begin{array}{l}32 \\
8,7\end{array}$ & 2,65 & NK \\
\hline $\begin{array}{l}\text { 6. Bir kişinin ismini, bana söylendik- } \\
\text { ten hemen sonra unuturum. }\end{array}$ & $\begin{array}{r}\mathrm{f} \\
\% \\
\end{array}$ & $\begin{array}{l}147 \\
40,1 \\
\end{array}$ & $\begin{array}{l}110 \\
30,0 \\
\end{array}$ & $\begin{array}{l}57 \\
15,5 \\
\end{array}$ & $\begin{array}{l}30 \\
8,2 \\
\end{array}$ & $\begin{array}{l}23 \\
6,3 \\
\end{array}$ & 2,10 & $\mathrm{KM}$ \\
\hline $\begin{array}{l}\text { 7. Yaptığım şeyin farkında olmaksızın } \\
\text { otomatiğe bağlanmış gibi yapıyorum. }\end{array}$ & $\begin{array}{r}\mathrm{f} \\
\%\end{array}$ & $\begin{array}{l}71 \\
19,3 \\
\end{array}$ & $\begin{array}{l}105 \\
28,6\end{array}$ & $\begin{array}{l}94 \\
25,6 \\
\end{array}$ & $\begin{array}{l}60 \\
16,3 \\
\end{array}$ & $\begin{array}{l}37 \\
10,1 \\
\end{array}$ & 2,69 & NK \\
\hline $\begin{array}{l}\text { 8. Aktiviteleri gerçekte ne olduklarına } \\
\text { dikkat etmeden acele ile yerine getiri- } \\
\text { rim. }\end{array}$ & $\begin{array}{r}\mathrm{f} \\
\%\end{array}$ & $\begin{array}{l}87 \\
23,7\end{array}$ & $\begin{array}{l}120 \\
32,7\end{array}$ & $\begin{array}{l}82 \\
22,3\end{array}$ & $\begin{array}{l}49 \\
13,4\end{array}$ & $\begin{array}{l}29 \\
7,9\end{array}$ & 2,49 & $\mathrm{KM}$ \\
\hline $\begin{array}{l}\text { 9. Başarmak istediğim hedeflere öyle } \\
\text { çok odaklanırım ki o hedeflere ulaş- } \\
\text { mak için şu an ne yapıyor olduğumun } \\
\text { farkında olmam. }\end{array}$ & $\begin{array}{r}\mathrm{f} \\
\%\end{array}$ & $\begin{array}{l}47 \\
12,8\end{array}$ & $\begin{array}{l}77 \\
21,0\end{array}$ & $\begin{array}{l}128 \\
34,9\end{array}$ & $\begin{array}{l}67 \\
18,3\end{array}$ & $\begin{array}{l}48 \\
13,1\end{array}$ & 2,97 & NK \\
\hline $\begin{array}{l}\text { 10. İşleri veya görevleri ne yaptığımın } \\
\text { farkında olmaksızın otomatik olarak } \\
\text { yaparım. }\end{array}$ & $\begin{array}{r}\mathrm{f} \\
\%\end{array}$ & $\begin{array}{l}72 \\
19,6\end{array}$ & $\begin{array}{l}116 \\
31,6\end{array}$ & $\begin{array}{l}92 \\
25,1\end{array}$ & $\begin{array}{l}58 \\
15,8\end{array}$ & $\begin{array}{l}29 \\
7,9\end{array}$ & 2,60 & NK \\
\hline $\begin{array}{l}\text { 11. Kendimi bir kulağımla birini } \\
\text { dinlerken aynı zamanda başka bir şeyi } \\
\text { de yaparken bulurum. }\end{array}$ & $\begin{array}{r}\mathrm{f} \\
\%\end{array}$ & $\begin{array}{l}47 \\
12,8\end{array}$ & $\begin{array}{l}77 \\
21,0\end{array}$ & $\begin{array}{l}93 \\
25,3\end{array}$ & $\begin{array}{l}100 \\
27,2\end{array}$ & $\begin{array}{l}50 \\
13,6\end{array}$ & 3,07 & $\mathrm{~K}$ \\
\hline $\begin{array}{l}\text { 12. Gideceğim yerlere farkında olma- } \\
\text { dan gidiyor, sonra da oraya neden } \\
\text { gittiğime şaşırıyorum. }\end{array}$ & $\begin{array}{r}\mathrm{f} \\
\%\end{array}$ & $\begin{array}{l}148 \\
40,3\end{array}$ & $\begin{array}{l}78 \\
21,3\end{array}$ & $\begin{array}{l}71 \\
19,3\end{array}$ & $\begin{array}{l}38 \\
10,4\end{array}$ & $\begin{array}{l}32 \\
8,7\end{array}$ & 2,25 & $\mathrm{KM}$ \\
\hline $\begin{array}{l}\text { 13. Kendimi gelecek veya geçmişle } \\
\text { meşgul bulurum. }\end{array}$ & $\begin{array}{r}\mathrm{f} \\
\% \\
\end{array}$ & $\begin{array}{l}44 \\
12,0 \\
\end{array}$ & $\begin{array}{l}57 \\
15,5 \\
\end{array}$ & $\begin{array}{l}82 \\
22,3 \\
\end{array}$ & $\begin{array}{l}109 \\
29,7 \\
\end{array}$ & $\begin{array}{l}75 \\
20,4 \\
\end{array}$ & 3,31 & $\mathrm{~K}$ \\
\hline $\begin{array}{l}\text { 14. Kendimi yaptığım işlere dikkatimi } \\
\text { vermemiş bulurum }\end{array}$ & $\begin{array}{r}\mathrm{f} \\
\% \\
\end{array}$ & $\begin{array}{l}84 \\
22,9 \\
\end{array}$ & $\begin{array}{l}80 \\
21,8 \\
\end{array}$ & $\begin{array}{l}95 \\
25,9 \\
\end{array}$ & $\begin{array}{l}71 \\
19,3 \\
\end{array}$ & $\begin{array}{l}37 \\
10,1 \\
\end{array}$ & 2,71 & NK \\
\hline $\begin{array}{l}\text { 15. Ne yediğimin farkında olmaksızın } \\
\text { atıştırıyorum. }\end{array}$ & $\begin{array}{r}\mathrm{f} \\
\%\end{array}$ & $\begin{array}{l}140 \\
38,1\end{array}$ & $\begin{array}{l}75 \\
20,4 \\
\end{array}$ & $\begin{array}{l}61 \\
16,6\end{array}$ & $\begin{array}{l}38 \\
10,4 \\
\end{array}$ & $\begin{array}{l}53 \\
14,4 \\
\end{array}$ & 2,42 & $\mathrm{KM}$ \\
\hline
\end{tabular}

(K. :Katılıyorum; N.K. : Ne Katılıyorum Ne Katılmıyorum; KM: Katılmıyorum)

Tablo 4'te belirtildiği üzere ölçeğin yüksek ortalamaya sahip maddelere örnek olarak şunlar verilebilir: "M11: Kendimi bir kulağımla birini dinlerken ayn zamanda başka bir şeyi de yaparken bulurum $(X=3,07)$ " ve "M13: Kendimi gelecek veya geçmişle meşgul bulurum. $(X=3,31)$ ". Bu sonuçlara 
göre lise öğrencilerinin bulunduğu ana odaklanamama, aynı anda başka işlerle de meşgul olduklarını göstermektedir. Tablo 4 'te görüldüğü gibi, çalışmaya katılan öğrenciler ölçekteki maddelerin büyük kısmını "Ne Katılıyorum Ne Katılmıyorum" ve "Katılmıyorum" diye belirtmişlerdir.

\section{Lise Öğrencilerinin Merak ve Keşfetme Düzeyleri İle Bilinçli Farkın- dalık Düzeyleri Arasında Cinsiyet Değişkenine Göre Anlamlı Bir İliş- ki Var midır?}

Araştırmanın üçüncü alt problemi olan “Lise öğrencilerinin merak ve keşfetme düzeyleri ile bilinçli farkındalık düzeyleri arasında cinsiyet değişkenine göre anlamlı bir ilişki var mıdır?" sorusuna ilişkin bulgular aşağıda (Tablo 5) yer almaktadır.

Tablo 5. Lise Öğrencilerinin Meraklılık ve Keşfetme Düzeyleri ile Bilinçli Farkındalık Düzeyleri Arasındaki Cinsiyet Açısından Korelasyon Analizi

\begin{tabular}{|c|c|c|c|c|c|c|}
\hline \multirow{2}{*}{\multicolumn{3}{|c|}{ Cinsiyet }} & \multirow{3}{*}{$\begin{array}{l}\text { Esneklik B. } \\
1\end{array}$} & \multirow{3}{*}{$\begin{array}{l}\text { Kabullenme } \\
\text { Boyutu } \\
, 022\end{array}$} & \multirow{3}{*}{$\begin{array}{l}\text { Merak Top. } \\
, 785^{* *}\end{array}$} & \multirow{3}{*}{$\begin{array}{l}\text { Bilinçli } \\
\text { Farkındalık } \\
-208^{* *}\end{array}$} \\
\hline & & & & & & \\
\hline \multirow[t]{12}{*}{ Kadın } & Esneklik Boyutu & Korelasyon & & & & \\
\hline & & $\mathrm{p}$ & & 781 & 000 & 009 \\
\hline & & $\mathrm{N}$ & 157 & 157 & 157 & 157 \\
\hline & Kabullenme & Korelasyon & ,022 & 1 & ,637" & ,089 \\
\hline & Boyutu & $\mathrm{p}$ & ,781 & & ,000 & ,266 \\
\hline & & $\mathrm{N}$ & 157 & 157 & 157 & 157 \\
\hline & Merak Toplam & Korelasyon & ,785 & 637"* & 1 &,- 105 \\
\hline & & $\mathrm{p}$ & ,000 & ,000 & & 189 \\
\hline & & $\mathrm{N}$ & 157 & 157 & 157 & 157 \\
\hline & Bilinçli & Korelasyon &,$- 208^{* *}$ & ,089 &,- 105 & 1 \\
\hline & Farkındalık & $\mathrm{p}$ & ,009 & ,266 & 189 & \\
\hline & & $\mathrm{N}$ & 157 & 157 & 157 & 157 \\
\hline \multirow[t]{12}{*}{ Erkek } & Esneklik Boyutu & Korelasyon & 1 & ,277" & ,836" & ,052 \\
\hline & & $\mathrm{p}$ & & 000 & ,000 & ,480 \\
\hline & & $\mathrm{N}$ & 183 & 183 & 183 & 183 \\
\hline & Kabullenme & Korelasyon & , 277 ** & 1 &, $759^{* *}$ & $152^{*}$ \\
\hline & Boyutu & $\mathrm{p}$ & ,000 & & ,000 & ,040 \\
\hline & & $\mathrm{N}$ & 183 & 183 & 183 & 183 \\
\hline & Merak Toplam & Korelasyon &, $836^{* *}$ & ,759** & 1 & 122 \\
\hline & & $\mathrm{p}$ & 000 & ,000 & & 099 \\
\hline & & $\mathrm{N}$ & 183 & 183 & 183 & 183 \\
\hline & Bilinçli & Korelasyon & ,052 & ,152* & ,122 & 1 \\
\hline & Farkındalık & $\mathrm{p}$ & 480 & ,040 & 099 & \\
\hline & & $\mathrm{N}$ & 183 & 183 & 183 & 210 \\
\hline
\end{tabular}

${ }^{* *} p<0,01$

${ }^{*} p<0,05$ 
Tablo 5'te lise öğrencilerinin meraklılık ölçeğinin esneklik boyutu ile bilinçli farkındalık düzeyleri arasındaki cinsiyet açısından korelasyon kadınlarda negatif yönde zayıf ilişki görülmektedir ( $r=-, 208 ; \mathrm{p}<, 01)$. Erkek öğrencilerde ise meraklılık ölçeğinin kabullenme boyutunda pozitif yönde, zayıf bir ilişki vardır ( $\mathrm{r}=, 152 ; \mathrm{p}<, 05)$.

\section{Lise Öğrencilerinin Merak Ve Keşfetme Düzeyleri İle Bilinçli Farkın- dalık Düzeyleri Arasında Sınıf Değişkenine Göre Anlamlı Bir İlişki Var midır?}

Araştırmanın dördüncü alt problemi olan “Lise öğrencilerinin merak ve keşfetme düzeyleri ile bilinçli farkındalık düzeyleri arasında sınıf değişkenine göre anlamlı bir ilişki var mıdır?" sorusuna ilişkin veriler Tablo 6 'da yer almaktadir.

Tablo 6. Lise Öğrencilerinin Meraklılık ve Keşfetme Düzeyleri ile Bilinçli Farkındalık Düzeyleri Arasındaki Sınıf Açısından Korelasyon Analizi

\begin{tabular}{|c|c|c|c|c|c|c|}
\hline \multirow[b]{2}{*}{ Sinif } & & & \multicolumn{3}{|c|}{ Kabullenme } & \multirow{2}{*}{$\begin{array}{c}\text { Bilinçli } \\
\text { Farkındalık }\end{array}$} \\
\hline & & & Esneklik B. & Boyutu & Merak Top. & \\
\hline \multirow{12}{*}{$\begin{array}{l}\text { Hazırlık } \\
\text { Sinıfı }\end{array}$} & Esneklik Boyutu & Korelasyon & 1 & 074 & $794^{* *}$ & 049 \\
\hline & & $\mathrm{p}$ & & 612 & ,000 & ,738 \\
\hline & & $\mathrm{N}$ & 49 & 49 & 49 & 49 \\
\hline & Kabullenme & Korelasyon & 074 & 1 & $665^{* *}$ &,- 179 \\
\hline & Boyutu & $\mathrm{p}$ & 612 & &, 000 & ,219 \\
\hline & & $\mathrm{N}$ & 49 & 49 & 49 & 49 \\
\hline & Merak Toplam & Korelasyon & $794^{* *}$ & $665^{* *}$ & 1 &,- 072 \\
\hline & & $\mathrm{p}$ &, 000 &, 000 & & 623 \\
\hline & & $\mathrm{N}$ & 49 & 49 & 49 & 49 \\
\hline & Bilinçli & Korelasyon & ,049 &,- 179 &,- 072 & 1 \\
\hline & Farkındalık & $\mathrm{p}$ & 738 & ,219 & 623 & \\
\hline & & $\mathrm{N}$ & 49 & 49 & 49 & 49 \\
\hline \multirow{12}{*}{ 9.Sinif } & Esneklik Boyutu & Korelasyon & 1 & ,061 & $720^{* *}$ &,- 045 \\
\hline & & $\mathrm{p}$ & &, 588 &, 000 & 687 \\
\hline & & $\mathrm{N}$ & 82 & 82 & 82 & 82 \\
\hline & Kabullenme & Korelasyon & 061 & 1 &, $737^{* *}$ & 210 \\
\hline & Boyutu & $\mathrm{p}$ &, 588 & &, 000 &, 058 \\
\hline & & $\mathrm{N}$ & 82 & 82 & 82 & 82 \\
\hline & Merak Toplam & Korelasyon & $720^{* *}$ &, $737^{* *}$ & 1 & ,115 \\
\hline & & $\mathrm{p}$ & ,000 & ,000 & & ,302 \\
\hline & & $\mathrm{N}$ & 82 & 82 & 82 & 82 \\
\hline & Bilinçli & Korelasyon &,- 045 & ,210 & 115 & 1 \\
\hline & Farkındalık & $\mathrm{p}$ & 687 & ,058 & ,302 & \\
\hline & & $\mathrm{N}$ & 82 & 82 & 82 & 82 \\
\hline \multirow{7}{*}{ 10.Sinif } & Esneklik Boyutu & Korelasyon & 1 & 212 & $814^{* *}$ &,- 098 \\
\hline & & $\mathrm{p}$ & &, 054 &, 000 & ,378 \\
\hline & & $\mathrm{N}$ & 83 & 83 & 83 & 83 \\
\hline & Kabullenme & Korelasyon & ,212 & 1 &, $741^{* *}$ &, 029 \\
\hline & Boyutu & $\mathrm{p}$ &, 054 & &, 000 & ,796 \\
\hline & & $\mathrm{N}$ & 83 & 83 & 83 & 83 \\
\hline & Merak Toplam & Korelasyon & $814^{* *}$ & $741^{* *}$ & 1 &,- 050 \\
\hline
\end{tabular}




\begin{tabular}{|c|c|c|c|c|c|c|}
\hline & & $\mathrm{p}$ & ,000 & 000 & & 652 \\
\hline & & $\mathrm{N}$ & 83 & 83 & 83 & 83 \\
\hline & Bilinçli & Korelasyon &,- 098 & 029 &,- 050 & 1 \\
\hline & Farkındalık & $\mathrm{p}$ & ,378 & ,796 & 652 & \\
\hline & & $\mathrm{N}$ & 83 & 83 & 83 & 83 \\
\hline 11.Sinif & Esneklik Boyutu & Korelasyon & 1 & $279^{*+}$ & , 858 & ,067 \\
\hline & & $\mathrm{p}$ & & ,009 & ,000 &, 539 \\
\hline & & $\mathrm{N}$ & 86 & 86 & 86 & 86 \\
\hline & Kabullenme & Korelasyon & ,279* & 1 & ,733" &, $239^{*}$ \\
\hline & Boyutu & $\mathrm{p}$ & 009 & & 000 & 027 \\
\hline & & $\mathrm{N}$ & 86 & 86 & 86 & 86 \\
\hline & Merak Toplam & Korelasyon &, $858^{* *}$ &, $733^{*+}$ & 1 & ,175 \\
\hline & & $\mathrm{p}$ & ,000 & ,000 & & 107 \\
\hline & & $\mathrm{N}$ & 86 & 86 & 86 & 86 \\
\hline & Bilinçli & Korelasyon & ,067 &, $239^{*}$ & 175 & 1 \\
\hline & Farkındalık & $\mathrm{p}$ &, 539 &, 027 & 107 & \\
\hline & & $\mathrm{N}$ & 86 & 86 & 86 & 86 \\
\hline 12.Sinif & Esneklik Boyutu & Korelasyon & 1 & 263 & $851^{* *}$ &,- 312 \\
\hline & & $\mathrm{p}$ & & 102 & ,000 &, 050 \\
\hline & & $\mathrm{N}$ & 40 & 40 & 40 & 40 \\
\hline & Kabullenme & Korelasyon & ,263 & 1 &, $730^{* *}$ &,- 072 \\
\hline & Boyutu & $\mathrm{p}$ & 102 & & ,000 & ,658 \\
\hline & & $\mathrm{N}$ & 40 & 40 & 40 & 40 \\
\hline & Merak Toplam & Korelasyon &, $851^{* *}$ & ,730* & 1 &,- 260 \\
\hline & & $\mathrm{p}$ & ,000 & ,000 & & 105 \\
\hline & & $\mathrm{N}$ & 40 & 40 & 40 & 40 \\
\hline & Bilinçli & Korelasyon &,- 312 &,- 072 &,- 260 & 1 \\
\hline & Farkındalık & $\mathrm{p}$ & ,050 & 658 & 105 & \\
\hline & & $\mathrm{N}$ & 40 & 40 & 40 & 67 \\
\hline
\end{tabular}

${ }^{*} p<0,05$

Tablo 6 incelendiğinde iki ölçek arasındaki sınıf bazında anlamlı ilişki sadece 11. sinıflarda görülmektedir. Meraklılık ve Keşfetme ölçeğinin kabullenme boyutu ile Bilinçli Farkındalık ölçeğinin verileri arasında 11. sınıflarda pozitif yönde orta düzeye yakın bir ilişki olduğu söylenebilir $(\mathrm{r}=, 239 ; \mathrm{p}<, 05)$.

Lise öğrencilerinin merak ve keşfetme düzeyleri ile bilinçli farkındalık düzeyleri arasında okul değişkenine göre anlamlı bir ilişki var midir?

Araştırmanın beşinci alt problemi olan "Lise öğrencilerinin merak ve keşfetme düzeyleri ile bilinçli farkındalık düzeyleri arasında okul türü değişkenine göre anlamlı bir ilişki var mıdır?" sorusuna ilişkin elde edilen bulgular Tablo 7'de verilmiştir: 
Tablo 7. Lise Öğrencilerinin Meraklılık ve Keşfetme Düzeyleri ile Bilinçli Farkındalık Düzeyleri Arasındaki Okul Türü Açısından Korelasyon Analizi

\begin{tabular}{|c|c|c|c|c|c|c|}
\hline \multicolumn{3}{|l|}{$\underline{\text { Okul }}$} & \multirow{2}{*}{$\begin{array}{l}\text { Esneklik } \\
\text { Boyutu } \\
1\end{array}$} & \multirow{2}{*}{$\begin{array}{l}\text { Kabullenme } \\
\text { Boyutu } \\
173\end{array}$} & \multirow{2}{*}{$\begin{array}{l}\text { Merak } \\
\text { Toplam } \\
, 822^{* *}\end{array}$} & \multirow{2}{*}{$\begin{array}{l}\text { Bilinçli } \\
\text { Farkındalık } \\
, 203^{*}\end{array}$} \\
\hline Mesleki ve Teknik & Esneklik & Korelasyon & & & & \\
\hline \multirow[t]{11}{*}{ Anadolu Lisesi } & Boyutu & $\mathrm{p}$ & & ,071 &, 000 &, 034 \\
\hline & & $\mathrm{N}$ & 110 & 110 & 110 & 110 \\
\hline & Kabullnme & Korelasyon &, 173 & 1 &, $703^{* *}$ &, 152 \\
\hline & Boyutu & $\mathrm{p}$ & ,071 & & ,000 & ,112 \\
\hline & & $\mathrm{N}$ & 110 & 110 & 110 & 110 \\
\hline & Merak Toplam & Korelasyon & $822^{* *}$ &, $703^{* *}$ & 1 & $235^{*}$ \\
\hline & & $\mathrm{p}$ &, 000 &, 000 & &, 014 \\
\hline & & $\mathrm{N}$ & 110 & 110 & 110 & 110 \\
\hline & Bilinçli & Korelasyon & $203^{*}$ & ,152 & $235^{*}$ & 1 \\
\hline & Farkındalık & $\mathrm{p}$ & ,034 & ,112 & ,014 & \\
\hline & & $\mathrm{N}$ & 110 & 110 & 110 & 123 \\
\hline \multirow[t]{12}{*}{ Anadolu Lisesi } & Esneklik & Korelasyon & 1 & ,102 & $721^{* *}$ &,- 158 \\
\hline & Boyutu & $\mathrm{p}$ & & ,321 &, 000 & 124 \\
\hline & & $\mathrm{N}$ & 96 & 96 & 96 & 96 \\
\hline & Kabullenme & Korelasyon & ,102 & 1 &, $763^{* *}$ & ,201 \\
\hline & Boyutu & $\mathrm{p}$ & ,321 & &, 000 & ,050 \\
\hline & & $\mathrm{N}$ & 96 & 96 & 96 & 96 \\
\hline & Merak Toplam & Korelasyon &, $721^{* *}$ &, $763^{* *}$ & 1 &, 037 \\
\hline & & $\mathrm{p}$ &, 000 &, 000 & & ,721 \\
\hline & & $\mathrm{N}$ & 96 & 96 & 96 & 96 \\
\hline & Bilinçli & Korelasyon &,- 158 & ,201 &, 037 & 1 \\
\hline & Farkındalık & $\mathrm{p}$ &, 124 &, 050 & ,721 & \\
\hline & & $\mathrm{N}$ & 96 & 96 & 96 & 105 \\
\hline \multirow{12}{*}{$\begin{array}{l}\text { Sosyal } \\
\text { Lisesi }\end{array}$} & Esneklik & Korelasyon & 1 & $258^{* *}$ & $861^{* *}$ &,$- 254^{* *}$ \\
\hline & Boyutu & $\mathrm{p}$ & &, 003 &, 000 &, 003 \\
\hline & & $\mathrm{N}$ & 134 & 134 & 134 & 134 \\
\hline & Kabullen & Korelasyon & $258^{* *}$ & 1 &, $713^{* *}$ &, 001 \\
\hline & me & $\mathrm{p}$ &, 003 & &, 000 & ,987 \\
\hline & Boyutu & $\mathrm{N}$ & 134 & 134 & 134 & 134 \\
\hline & Merak Toplam & Korelasyon & $861^{* *}$ & $713^{* *}$ & 1 &,$- 184^{*}$ \\
\hline & & $\mathrm{p}$ &, 000 &, 000 & &, 033 \\
\hline & & $\mathrm{N}$ & 134 & 134 & 134 & 134 \\
\hline & Bilinçli & Korelasyon &,$- 254^{* *}$ &, 001 &,$- 184^{*}$ & 1 \\
\hline & Farkındalık & $\mathrm{p}$ &, 003 & ,987 &, 033 & \\
\hline & & $\mathrm{N}$ & 134 & 134 & 134 & 139 \\
\hline
\end{tabular}

${ }^{* *} p<0,01{ }^{*} p<0,05$

Lise öğrencilerinin meraklılık ve keşfetme düzeyleri ile bilinçli farkındalık düzeyleri arasındaki okul türü açısından korelasyon tablosuna bakıldığında Mesleki ve Teknik Anadolu Lisesi verileri ile bilinçli farkındalık düzeyleri esneklik boyutunda pozitif yönde anlamlı bir ilişki olduğu görülmektedir ( $r=, 203 ; \mathrm{p}<, 05)$. Aynı zamanda meraklılık ölçeğinin toplamında da tek boyutlu olan bilinçli farkındalık ölçeği ile pozitif 
yönde zayıf ilişki bulunmaktadır $(\mathrm{r}=, 235 ; \mathrm{p}<, 05)$. Sosyal Bilimler Lisesi verilerinin esneklik boyutu ile bilinçli farkındalık verileri arasında negatif yönde anlamlı bir ilişki vardır $(\mathrm{r}=-, 254 ; \mathrm{p}<, 01)$. Sosyal Bilimler Lisesi'nin meraklılık ve keşfetme toplam puanı ile bilinçli farkındalık puanları da negatif yönde zayıf bir ilişki göstermektedir $(\mathrm{r}=-, 184 ; \mathrm{p}<, 05)$.

Lise öğrencilerinin merak ve keşfetme düzeyleri ile bilinçli farkındalık düzeyleri arasında akademik başarı (yılsonu ortalamasına) göre anlamlı bir ilişki var mıdır?

Araştırmanın altıncı alt problemi olan “Lise öğrencilerinin merak ve keşfetme düzeyleri ile bilinçli farkındalık düzeyleri arasında akademik başarı değişkenine göre anlamlı bir ilişki var mıdır?" sorusuna ilişkin veriler Tablo 8'de yer almaktadır:

Tablo 8. Lise Öğrencilerinin Meraklılık ve Keşfetme Düzeyleri ile Bilinçli Farkındalık Düzeyleri Arasındaki Akademik Başarı Açısından Korelasyon Analizi

\begin{tabular}{|c|c|c|c|c|c|c|}
\hline \multicolumn{3}{|c|}{ Akademik başarı } & \multirow{2}{*}{$\begin{array}{l}\text { Esneklik } \\
\text { Boyutu } \\
1\end{array}$} & \multirow{2}{*}{$\begin{array}{l}\text { Kabullenme } \\
\text { Boyutu } \\
, 041\end{array}$} & \multirow{2}{*}{$\begin{array}{c}\begin{array}{c}\text { Merak } \\
\text { Toplam }\end{array} \\
, 699^{* *}\end{array}$} & \multirow{2}{*}{$\begin{array}{r}\begin{array}{r}\text { Bilinçli } \\
\text { Farkındalık }\end{array} \\
-, 318\end{array}$} \\
\hline $25-44$ & Esneklik Boyutu & Korelasyon & & & & \\
\hline & & $\mathrm{p}$ & & 873 &, 001 & ,198 \\
\hline & & $\mathrm{N}$ & 18 & 18 & 18 & 18 \\
\hline & Kabullenme & Korelasyon & ,041 & 1 &, $743^{* *}$ & ,065 \\
\hline & Boyutu & $\mathrm{p}$ & 873 & &, 000 & ,799 \\
\hline & & $\mathrm{N}$ & 18 & 18 & 18 & 18 \\
\hline & Merak Toplam & Korelasyon & $699^{* *}$ &, $743^{* *}$ & 1 &,- 167 \\
\hline & & $\mathrm{p}$ &, 001 &, 000 & &, 508 \\
\hline & & $\mathrm{N}$ & 18 & 18 & 18 & 18 \\
\hline & Bilinçli & Korelasyon &,- 318 &, 065 &,- 167 & 1 \\
\hline & Farkındalık & $\mathrm{p}$ & ,198 & ,799 &, 508 & \\
\hline & & $\mathrm{N}$ & 18 & 18 & 18 & 18 \\
\hline \multirow[t]{12}{*}{$45-54$} & Esneklik Boyutu & Korelasyon & 1 &,- 194 & $801^{* *}$ &,- 152 \\
\hline & & $\mathrm{p}$ & & ,295 &, 000 & 415 \\
\hline & & $\mathrm{N}$ & 31 & 31 & 31 & 31 \\
\hline & Kabullenme & Korelasyon &,- 194 & 1 & $432^{*}$ & ,247 \\
\hline & Boyutu & $\mathrm{p}$ & ,295 & & ,015 & ,180 \\
\hline & & $\mathrm{N}$ & 31 & 31 & 31 & 31 \\
\hline & Merak Toplam & Korelasyon &, $801^{* *}$ & $432^{*}$ & 1 & ,011 \\
\hline & & $\mathrm{p}$ &, 000 &, 015 & & ,953 \\
\hline & & $\mathrm{N}$ & 31 & 31 & 31 & 31 \\
\hline & Bilinçli & Korelasyon &,- 152 & ,247 & ,011 & 1 \\
\hline & Farkındalık & $\mathrm{p}$ & ,415 & ,180 & ,953 & \\
\hline & & $\mathrm{N}$ & 31 & 31 & 31 & 32 \\
\hline \multirow[t]{2}{*}{$55-69$} & Esneklik Boyutu & Korelasyon & 1 & $206^{*}$ & $806^{* *}$ &,- 024 \\
\hline & & $\mathrm{p}$ & &, 040 & ,000 & 810 \\
\hline
\end{tabular}




\begin{tabular}{|c|c|c|c|c|c|c|}
\hline & & $\mathrm{N}$ & 100 & 100 & 100 & 100 \\
\hline & Kabullenme & Korelasyon & $206^{*}$ & 1 &, $746^{* *}$ & 033 \\
\hline & Boyutu & $\mathrm{p}$ & 040 & & ,000 & ,741 \\
\hline & & $\mathrm{N}$ & 100 & 100 & 100 & 100 \\
\hline & Merak Toplam & Korelasyon &, $806^{* *}$ &, $746^{* *}$ & 1 & ,004 \\
\hline & & $\mathrm{p}$ & ,000 & ,000 & & ,971 \\
\hline & & $\mathrm{N}$ & 100 & 100 & 100 & 100 \\
\hline & Bilinçli & Korelasyon &,- 024 & ,033 & ,004 & 1 \\
\hline & Farkındalık & $\mathrm{p}$ & 810 & ,741 & 971 & \\
\hline & & $\mathrm{N}$ & 100 & 100 & 100 & 108 \\
\hline$\overline{70-84}$ & Esneklik Boyutu & Korelasyon & 1 & $218^{* *}$ &, $832^{* *}$ & ,018 \\
\hline & & $\mathrm{p}$ & &, 007 &, 000 & 826 \\
\hline & & $\mathrm{N}$ & 153 & 153 & 153 & 153 \\
\hline & Kabullenme & Korelasyon &, $218^{* *}$ & 1 &, $723^{* *}$ & ,070 \\
\hline & Boyutu & $\mathrm{p}$ & ,007 & & 000 & ,393 \\
\hline & & $\mathrm{N}$ & 153 & 153 & 153 & 153 \\
\hline & Merak Toplam & Korelasyon &, $832^{* *}$ &, $723^{* *}$ & 1 & 052 \\
\hline & & $\mathrm{p}$ & ,000 &, 000 & &, 521 \\
\hline & & $\mathrm{N}$ & 153 & 153 & 153 & 153 \\
\hline & Bilinçli & Korelasyon & ,018 & 070 & ,052 & 1 \\
\hline & Farkındalık & $\mathrm{p}$ & ,826 & ,393 &, 521 & \\
\hline & & $\mathrm{N}$ & 153 & 153 & 153 & 167 \\
\hline $85-100$ & Esneklik Boyutu & Korelasyon & 1 & $414^{*}$ & $890^{* *}$ &,- 257 \\
\hline & & $\mathrm{p}$ & & 011 & ,000 & ,125 \\
\hline & & $\mathrm{N}$ & 37 & 37 & 37 & 37 \\
\hline & Kabullenme & Korelasyon &, $414^{*}$ & 1 &, $784^{* *}$ & , 181 \\
\hline & Boyutu & $\mathrm{p}$ & 011 & & ,000 & 283 \\
\hline & & $\mathrm{N}$ & 37 & 37 & 37 & 37 \\
\hline & Merak Toplam & Korelasyon &, $890^{* *}$ &, $784^{* *}$ & 1 &,- 085 \\
\hline & & $\mathrm{p}$ & 000 & ,000 & & 619 \\
\hline & & $\mathrm{N}$ & 37 & 37 & 37 & 37 \\
\hline & Bilinçli & Korelasyon &,- 257 & 181 &,- 085 & 1 \\
\hline & Farkındalık & $\mathrm{p}$ & , 125 & 283 & 619 & \\
\hline & & $\mathrm{N}$ & 37 & 37 & 37 & 41 \\
\hline
\end{tabular}

Tablo 8'e göre lise öğrencilerinin merak ve keşfetme düzeyleri ile bilinçli farkındalık düzeyleri arasında akademik başarıya (yılsonu ortalamasına) göre anlamlı bir ilişki bulunamamıştır.

\section{Lise öğrencilerinin merak düzeyleri, bilinçli farkındalık düzeyleri ve cinsiyetin ortak etkisine bağlı olarak anlamlı bir farklılık var mıdır?}

Araştırmanın yedinci alt problemi olan "Lise öğrencilerinin merak düzeyleri, bilinçli farkındalık düzeyleri ve cinsiyetin ortak etkisine bağlı olarak anlamlı bir farklılık var mıdır?" sorusuna ilişkin veriler Tablo 9'dadır: 
Tablo 9. Lise Öğrencilerinin Bilinçli Farkındalık ve Cinsiyete Göre Merak ve Keşfetme Puanlarmin Betimsel Istatistikleri

\begin{tabular}{lllll}
\hline Merak Düzey & Cinsiyet & $\mathbf{X}$ & ss & N \\
\hline Düşük & Kadın & 38,00 & 6,48 & 4 \\
& Erkek & 28,83 & 5,84 & 6 \\
& Toplam & 32,50 & 7,44 & 10 \\
\hline Orta & Kadın & 42,19 & 8,56 & 136 \\
& Erkek & 40,19 & 9,22 & 129 \\
& Toplam & 41,22 & 8,93 & 265 \\
\hline Yüksek & Kadın & 38,29 & 9,23 & 17 \\
& Erkek & 41,41 & 9,69 & 48 \\
& Toplam & 40,60 & 9,60 & 65 \\
\hline Toplam & Kadın & 41,66 & 8,65 & 157 \\
& Erkek & 40,14 & 9,47 & 183 \\
& Toplam & 40,84 & 9,12 & 340 \\
\hline
\end{tabular}

Merak ve keşfetme düzeyi düşük olan öğrencilerin ortalaması $X=32,50$ iken, orta düzeyde merak puanına sahip olan lise öğrencilerinin ortalaması $X=41,22$ ve yüksek merak ortalamasına sahip öğrencilerin toplam ortalaması $X=40,60$ olarak görülmektedir. Düşük ve orta merak düzeyleri cinsiyet açısından kadınlarda yüksek iken, Merak düzeyi yüksek ve toplam merak puanlarında erkek öğrencilerin puan ortalamaları kız öğrencilere göre daha yüksektir. Tablo $10^{\prime}$ de cinsiyet değişkenine göre lise öğrencilerinin meraklılık düzeylerinin karşılaştırılmasına ilişkin ANOVA sonuçları gösterilmektedir.

Tablo 10. Lise Öğrencilerinin Bilinçli Farkındalık ve Cinsiyete Göre Merak ve Keşfetme Puanlarını Anova Sonuçları

\begin{tabular}{|c|c|c|c|c|c|c|c|}
\hline \multirow{2}{*}{$\frac{\text { Varyansın Kaynağı }}{\text { Merak Düzeyi }}$} & \multicolumn{2}{|c|}{ Kareler ToplamıSd } & \multirow{2}{*}{$\begin{array}{l}\begin{array}{l}\text { Kareler } \\
\text { Ortalamas1 }\end{array} \\
304,573\end{array}$} & \multirow{2}{*}{$\frac{\mathbf{F}}{3,784}$} & \multirow{2}{*}{$\frac{\mathrm{p}}{, 024^{*}}$} & \multicolumn{2}{|r|}{$\eta^{2}$} \\
\hline & 609,145 & 2 & & & & 022 & \\
\hline Cinsiyet & 126,673 & 1 & 126,673 & & & 005 & \\
\hline$M D * C$ & 425,706 & 2 & 212,853 & & & 016 & \\
\hline Hata & 26881,824 & 334 & 80,485 & & & & \\
\hline Toplam & 595494,000 & 340 & & & & & \\
\hline
\end{tabular}

Tablo 10'daki verilere göre lise öğrencilerinin meraklılık düzeyleri ile bilinçli farkındalık düzeyleri ortalama puanları arasında anlamlı farklılık görülmektedir, $(\mathrm{F}=3,784 ; \mathrm{p}<0,05)$. Bu durum meraklılık düzeyinin bilinçli farkındalık üzerinde anlamlı etkisinin olduğunu göstermektedir. Ancak bilinçli farkındalık puanlarının cinsiyete göre ve öğrencilerin meraklılık düzeylerine göre anlamlı bir farklılık göstermemektedir $(\mathrm{F}=2,645$; 
$\mathrm{p}>0,05)$. Bu durum lise öğrencilerinin bilinçli farkındalık üzerinde cinsiyetin önemli bir etkisi olmadığını gösterir.

Lise öğrencilerinin merak düzeylerinde, bilinçli farkındalık ve okul türlerinin ortak etkisine bağlı olarak anlamlı bir farklılık var mıdır?

Araştırmanın dokuzuncu alt problemi olan "Lise öğrencilerinin merak düzeylerinde, bilinçli farkındalık düzeyleri ve okul türlerinin ortak etkisine bağlı olarak anlamlı bir farklılık var mıdır?" sorusuna ilişkin bulgular Tablo 11'de yer almaktadır:

Tablo 11. Lise Öğrencilerinin Bilinçli Farkındalık ve Okul Türlerine Göre Merak ve Keşfetme Puanlarnin Betimsel İstatistikleri

\begin{tabular}{|c|c|c|c|c|}
\hline Merak Düzeyi & Okul Türü & $\mathbf{x}$ & ss & $\mathbf{N}$ \\
\hline \multirow[t]{4}{*}{ Düşük } & $\begin{array}{l}\text { Mesleki ve Teknik } \\
\text { Lisesi }\end{array}$ & Anadolu $_{26,50}$ & 5,56 & 4 \\
\hline & Anadolu Lisesi & 33,50 & 3,53 & 2 \\
\hline & Sosyal Bilimler Lisesi & 38,00 & 6,48 & 4 \\
\hline & Toplam & 32,50 & 7,44 & 10 \\
\hline \multirow[t]{4}{*}{$\overline{\text { Orta }}$} & $\begin{array}{l}\text { Mesleki ve Teknik } \\
\text { Lisesi }\end{array}$ & Anadolu $_{39,14}$ & 9,11 & 84 \\
\hline & Anadolu Lisesi & 41,94 & 9,08 & 72 \\
\hline & Sosyal Bilimler Lisesi & 42,34 & 8,47 & 109 \\
\hline & Toplam & 41,22 & 8,93 & 265 \\
\hline \multirow[t]{4}{*}{ Yüksek } & $\begin{array}{l}\text { Mesleki ve Teknik } \\
\text { Lisesi }\end{array}$ & Anadolu $_{43,90}$ & 10,84 & 22 \\
\hline & Anadolu Lisesi & 38,45 & 7,95 & 22 \\
\hline & Sosyal Bilimler Lisesi & 39,38 & 9,31 & 21 \\
\hline & Toplam & 40,60 & 9,60 & 65 \\
\hline \multirow[t]{4}{*}{ Toplam } & $\begin{array}{l}\text { Mesleki ve Teknik } \\
\text { Lisesi }\end{array}$ & Anadolu $_{39,63}$ & 9,85 & 110 \\
\hline & Anadolu Lisesi & 40,96 & 8,90 & 96 \\
\hline & Sosyal Bilimler Lisesi & 41,75 & 8,59 & 134 \\
\hline & Toplam & 40,84 & 9,12 & 340 \\
\hline
\end{tabular}

Tablo 11 incelendiğinde toplamda en yüksek meraklılık puan ortalaması Sosyal Bilimler Lisesi'ne ait verilerdir $(X=41,75)$. En düşük ise Mesleki ve Teknik Anadolu Lisesi öğrencilerinin ortalamasıdır $(X=39,63)$. Lise öğrencilerinin tablo 16 'da okul türlerine ve bilinçli farkındalık puanları arasındaki anlamlı farklılığa ilişkin ANOVA sonuçları Tablo 12'de verilmiştir. 
Tablo 12. Lise Öğrencilerinin Bilinçli Farkındalık ve Okul Türlerine Göre Merak ve Keşfetme Puanlarının Anova Sonuçları

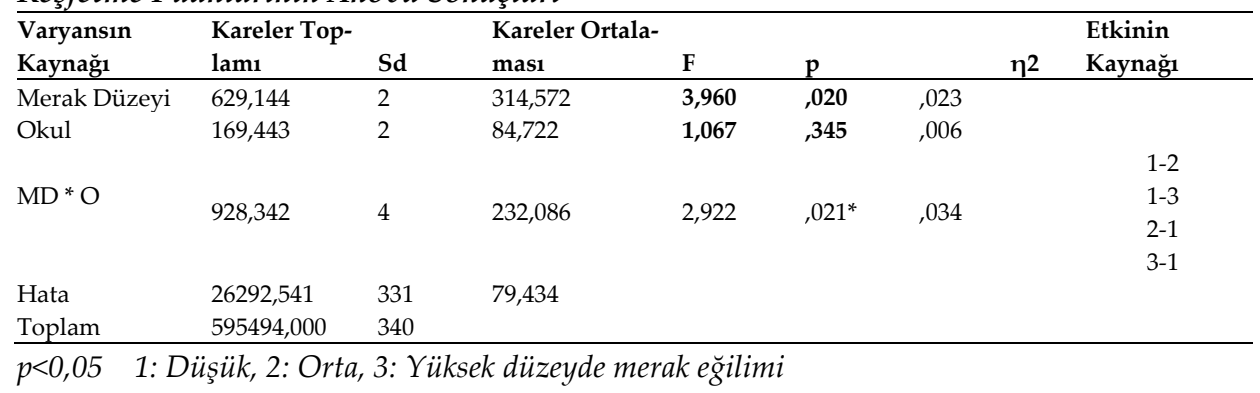

Lise öğrencilerinin meraklılık düzeyleri ile bilinçli farkındalık arasında okul türünün önemli bir etken olduğu görülmektedir $(\mathrm{F}=2,922$; $\mathrm{p}<0,05)$. Sheffe testi sonuçlarına göre, Sosyal Bilimler Lisesi Öğrencileri lehine anlamlı farklılık olduğu görülmüştür.

9)Lise öğrencilerinin merak düzeyleri, bilinçli farkındalık düzeyleri ve akademik başarılarının (yılsonu ortalamasının) ortak etkisine bağlı olarak anlamlı bir farklılık göstermekte midir?

Araştırmanın onuncu alt problemi olan "Lise öğrencilerinin merak düzeyleri, bilinçli farkındalık düzeyleri ve okul türlerinin ortak etkisine bağlı olarak anlamlı bir farklılık göstermekte midir?" sorusuna ilişkin veriler Tablo 13'tedir:

Lise öğrencilerinin akademik başarılarına ilişkin tablo 13'e bakıldığında akademik başarıları 85-100 arasında olan ve düşük merak düzeyine sahip olan öğrencilerin ortalaması $(X=37,75)$ olduğu görülmektedir. Orta düzeyde merak değerine sahip, 85-100 arasında başarı ortalamasına sahip öğrencilerin ortalaması $(X=37,45)$ ve $X=40,00$ puan ortalamalarına sahip öğrencilerin, yüksek merak değerinde 85-100 arasında yılsonu başarı puanları olduğu görülmektedir. Toplam ölçek puanında 25-44 başarı puanına sahip öğrencilerin ortalaması ise $(X=45,05)^{\prime}$ dir. Tablo 14 'te lise öğrencilerinin düşük, orta ve yüksek merak düzeyinin, bilinçli farkındalık düzeyleri ve yılsonu ortalamalarının ortak etkisine dair ANOVA sonuçları analiz edilmiştir. 
Tablo 13. Lise Öğrencilerinin Bilinçli Farkındalık ve Akademik Başarılarına Göre Merak ve Keşfetme Puanlarının Betimsel İstatistikleri

\begin{tabular}{lllll}
\hline Merak Düzey & A.Başar1 & $\mathbf{X}$ & ss & N \\
\hline Düşük & $55-69$ & 33,50 & 3,53 & 2 \\
& $70-84$ & 26,75 & 5,73 & 4 \\
& $85-100$ & 37,75 & 6,89 & 4 \\
& Toplam & 32,50 & 7,44 & 10 \\
\hline Orta & $0-44$ & 45,15 & 10,10 & 14 \\
& $45-54$ & 42,30 & 10,32 & 26 \\
& $55-69$ & 41,30 & 7,47 & 81 \\
& $70-84$ & 41,00 & 9,12 & 120 \\
& $85-100$ & 37,45 & 9,20 & 24 \\
& Toplam & 41,44 & 8,93 & 265 \\
\hline Yüksek & $25-44$ & 39,20 & 11,69 & 5 \\
& $45-54$ & 41,40 & 12,13 & 5 \\
& $55-69$ & 39,82 & 6,74 & 29 \\
& $70-84$ & 41,34 & 10,54 & 9 \\
& $85-100$ & 40,00 & 10,53 & 65 \\
\hline Toplam & 40,60 & 9,60 & 1 \\
& $0-24$ & 43,00 &. & 18 \\
& $25-44$ & 45,05 & 10,87 & 31 \\
& $45-54$ & 42,16 & 10,42 & 100 \\
& $55-69$ & 40,90 & 7,35 & 153 \\
& $70-84$ & 40,69 & 9,56 & 37 \\
& $85-100$ & 38,10 & 9,16 & 340 \\
\hline
\end{tabular}

Tablo 14. Lise Öğrencilerinin Bilinçli Farkındalık ve Akademik Başarılarına Göre Merak ve Keşfetme Puanlarının Anova Sonuçları

\begin{tabular}{|c|c|c|c|c|c|c|c|}
\hline Varyansın Kaynağ1 & $\begin{array}{l}\text { Kareler } \\
\text { Toplamı }\end{array}$ & Sd & $\begin{array}{l}\text { Kareler } \\
\text { Ortalaması }\end{array}$ & $\mathbf{F}$ & $\mathrm{p}$ & & $\eta 2$ \\
\hline Merak Düzeyi & 580,372 & 2 & 290,186 & 3,594 & ,029 & ,022 & \\
\hline Akademik Başarı & 242,321 & 5 & 48,464 & 600 & ,700 & ,009 & \\
\hline $\mathrm{MD} * \mathrm{AB}$ & 658,583 & 6 & 109,764 & 1,359 & 231 & ,024 & \\
\hline Hata & 26323,564 & 326 & 80,747 & & & & \\
\hline Toplam & 595494,000 & 340 & & & & & \\
\hline
\end{tabular}

Ortak etkiyi ölçmek amacıyla yapılan Tablo 14'teki ANOVA sonuçlarına göre lise öğrencilerinin meraklılık düzeyleri, akademik başarı ve bilinçli farkındalık düzeyleri üzerinde anlamlı bir farklılığa ulaşmamıştır ve önemli bir etkisi olmadığı görülmektedir.

\section{Tartışma ve Sonuç}

Lise öğrencilerinin meraklılık ve keşfetme eğilim düzeyleri ile bilinçli farkındalık düzeyleri arasındaki ilişkinin incelenmesi amacıyla yapılan 
bu çalışmada; öğrencilerin meraklılık düzeyleri, bilinçli farkındalık düzeyleri ve meraklılık ile bilinçli farkındalıkları arasındaki ilişkinin olup olmadığ1 ortaya konulmaya çalışılmıştır. Araştırmada ilk olarak değişkenler arası ilişkiler incelenmiştir. Aynı zamanda öğrencilerin meraklılık eğilimlerinin, bilinçli farkındalıklarına ve cinsiyet, okul türü ve akademik başarılarına göre anlamlı bir farklılık gösterip göstermediği incelenmiştir.

Araştırmada elde edilen bulgular, lise öğrencilerinin ortalamanın üzerinde merak düzeylerinin olduğunu göstermektedir. Öğretmen adayları ile yapılan benzer bir çalışmada meraklılık düzeylerinin ölçek orta puanının üstünde olduğu fakat derinlik alt boyutu ortalamasının genişlik ortalamasından daha düşük olduğu tespit edilmiştir (Deringöl, Yaman, Özsarı ve Gülten, 2010). Bu çalışmada ise, lise öğrencilerinde belirsizliği kabullenme alt boyutu ortalamasının 12,60 olması; ölçeğin orta değerin üzerinde olduğunu göstermektedir. Buna göre lise öğrencilerinde belirsizliği kabullenme, farklı olana ilgi duyma, bilinmeyenden korkmama gibi duyguların, bir yetişkinden daha fazla olduğu düşünülmektedir. Ancak bilinçli farkındalık ölçeğine dair betimsel istatistiklere göre tek boyutlu ölçekte ortalamanın $(X=40,84)$ düşük olduğu görülmektedir. Bilinçli farkındalık ölçeği sonuçlarına göre lise öğrencileri ortalamanın altında bir farkındalığa sahip olduğu görülmüştür.

Merak düzeylerinin bilinçli farkındalık ile etkisi incelendiğinde, meraklılık ölçeğinin esneklik boyutu ile bilinçli farkındalık düzeyleri cinsiyet açısından kadınlarda negatif yönde zayıf ilişki göstermektedir. Bu durum kız öğrencilerin bilinçli farkındalık yapı taşlarından olan duygu ve düşünce düzenleme becerilerinin ergenlik dönemindeki olumsuz yansımalarından kaynaklı olabilir. Gündüz (2016) çalışmasında, bilinçli farkındalık ile duygu düzenleme güçlüğü arasında negatif yönlü ilişki bulunduğunu ortaya koymuştur. Erkek öğrencilerde ise meraklılık ölçeğinin kabullenme boyutunda pozitif yönde zayıf bir ilişki olduğu görülmüştür.

Araştırmada elde edilen bulgular, lise öğrencilerinin meraklılık ve keşfetme düzeyleri ile bilinçli farkındalık düzeyleri arasında 11. sınıflarda pozitif yönde orta düzeye yakın bir ilişki olduğunu göstermektedir. Ayrıca meraklılık ölçeği ile bilinçli farkındalık düzeyleri arasında okul türü bazında pozitif yönde anlamlı bir ilişki olduğu belirlenmiştir. Bu 
ilişkinin Mesleki ve Teknik Anadolu Lisesi öğrencilerinin bilinçli farkındalık düzeyleri ile meraklılık ölçeğinin esneklik boyutunda pozitif yönde anlamlı olduğu görülmektedir. Bu durum meslek lisesi öğrencilerinin atölye derslerinde keşfederek öğrenmeye uygun olmasından kaynaklanabilir. Çünkü meslek lisesi öğrencileri daha çok araştırma, deneme ve yanılma yöntemiyle öğrenmektedir. Aynı zamanda meraklılık ölçeğinin toplamında da okul türü bazında tek boyutlu olan bilinçli farkındalık ölçeği ile pozitif yönde zayıf ilişki bulunmaktadır. Ancak bu iki ölçek arasındaki ilişki düzeyi beklenilenden daha düşük çıkmıştır. Yani meraklılık düzeyi yüksek olan öğrencilerin bilinçli farkındalığı da çok yüksektir demek doğru olmayacaktır. Bu durum merak ve farkındalık olgularının birbiriyle beklenilen kadar ilişkili olmadıklarını göstermiştir. Şahin (2019) çalışmasında, üniversite öğrencilerinin bilinçli farkındalık puanları ile yaşam doyumu puanları arasında pozitif yönlü anlamlı düzeyde bir ilişki bulmuştur. Fakat yapılan analiz sonuçlarına göre akademik başarı açısından iki ölçek arasında korelasyon olmadığı tespit edilmiştir. Yani okuldaki not ortalaması yüksek öğrencilerin merak ve keşfetme düzeyleri ile bilinçli farkındalık düzeyleri arasında anlamlı bir ilişki yoktur. Bu durum lisansüstü öğrencileri gibi lise öğrencilerinin buluş yoluyla eğitim almadığının göstergesi olabilir. Yeşilyurt (2019)'a göre sunuş yoluyla verilen eğitimin ezbere ve anlamlı öğrenmeye dayalı öğrencinin merak ve keşfetme duygusunu arttırmadığı bilinmektedir.

Araştırmada elde edilen bir diğer sonuca göre, lise öğrencilerinin meraklılık düzeyleri ile bilinçli farkındalık düzeyleri ortalama puanları arasinda anlamlı farklılık vardır $(\mathrm{F}=3,784 \mathrm{p}<0,05)$. Bu durum öğrencilerin meraklılık düzeyinin, bilinçli farkındalık üzerinde anlamlı etkisinin olduğunu gösterir. Ancak lise öğrencilerinin merak düzeyleri, bilinçli farkındalık düzeyleri ve cinsiyetin ortak etkisine bağlı olarak anlamlı bir farklılık göstermemektedir. Azak (2018) yaptığı çalışmasında hemşirelik öğrencilerin bilinçli farkındalık düzeyi ile öğrencilerin yaşları, cinsiyetleri, sınıfları ve doğum yerleri açısından anlamlı farklılıklar olmadığını, algılanan gelir düzeyi ve en uzun süre yaşadıkları bölge açısından anlamlı farklılıklar ortaya çıktığını belirtmiştir. Bunun aksine Deringöl ve arkadaşları (2010) çalışmasında meraklılık düzeylerinin karşılaştırılması sonucunda kız ve erkek öğrencilerin ortalama puanlarının anlamlı bi- 
çimde farklılaştığı ve farkın kız öğrenciler yönünde yüksek olduğunu belirtmiştir.

Araştırmanın sonuçlara göre lise öğrencilerinin meraklılık düzeyleri ile bilinçli farkındalık düzeyleri arasında okul türünün önemli bir etken olduğu görülmektedir $(\mathrm{F}=2,922 ; \mathrm{p}<0,05)$. Lise öğrencilerinin bilinçli farkındalık düzeyleri ve okul türlerine göre merak ve keşfetme düzeylerinde en yüksek meraklılık puan ortalamasına sahip Sosyal Bilimler Lisesi öğrencileri lehine anlamlı farklılık olduğu görülmüştür. Bu durum Sosyal Bilimler Lisesi öğrencilerinin merak düzeyleri ve bilinçli farkındalık düzeyleri açısından, diğer okul türlerine göre pozitif yönde bir farklılık olduğunu göstermektedir. Lise öğrencilerinin meraklılık düzeyleri, akademik başarı ve bilinçli farkındalık düzeyleri üzerinde anlamlı bir farkl1lığa ulaşmamıştır. Arana (2006)'nın bilinçli farkındalığa dayalı stres azaltma programının utangaçlığın azaltılmasında etkili olduğunu belirttiği çalışması bulunmaktadır. Bu durum meraklılık eğilimi için de kısmen geçerlidir. Araştırmada lise öğrencilerinin meraklılık eğilimleri ile bilinçli farkındalık arasındaki anlamlı farklılığın öğrencilerin cinsiyet ve akademik başarılarına etkisi olmadığı görülmektedir. Bu bağlamda şu öneriler sunulabilir:

- Ülkemizde bilinçli farkındalık konusu üzerine yapılan çalışmaların azlığı göz önüne alınarak yeni araştırma alanları oluşturabilir.

- Bilinçli farkındalık ve psikolojinin çoğu alanında ilişkisel bir araştırma yapılması alan yazına büyük katkı sağlayacaktır.

- Eğitimcilerin ve öğrencilerin bilinçli farkındalık alanında öğrencilere katkı sağlayacak yayınları takip etmeleri sağlanmalıdır. 


\title{
EXTENDED ABSTRACT
}

\section{Examining the Relationship Between the Levels of Curiosity and Mindfulness of High School Students}

\author{
Gürbüz Ocak- Emine Akkaş Baysal-Ulviye Yer \\ Afyon Kocatepe University
}

Curiosity contributes greatly to learning activities in education. The task of a teacher is to ensure permanent learning by arousing curiosity. Curiosity allows people to focus on a particular area, event or object. Curiosity that leads individuals to discover enables them to continue their efforts. Curiosity brings interest. It is observed that students with a high level of curiosity are more successful and productive in the field they are interested in.

Mindfulness means focusing attention on what is being done at the moment and being aware of the action being taken. The mindfulness state is formed by the components of self-knowledge and orientation, emotion and attention regulation in individual. It is the state of being aware of situation that is happening without making any judgment as positive or negative about the events experienced. Mindlessness is conscious refusal to accept or deal with a thought, emotion, intention. It means being in the moment, noticing and not judging.

The feeling of curiosity enables the person to focus on that "moment". For this reason, it is important to examine the relationship between curiosity and mindfulness. In the mindfulness, it is important to keep attention both internally and externally. In this case, the feeling of curiosity is an important step in maintaining attention and focusing. Students' feelings of interest, motivation, attention and curiosity constitute important rings in education. The stronger the relationship of these rings with each other, the more permanent learning is. For this reason, determining the effect of curiosity and discovery levels of high school students on their mindfulness plays an important role in terms of education.

This research aims to examine the relationship between the curiosity levels and mindfulness levels of high school students according to their gender, class, school type and academic achievement variables. The rese- 
arch was designed as relational survey model. 367 high school students participated in this study, in which stratified sampling method, one of random sampling types, was used. In order to determine the sample, the universe of the study is divided into layers. First of all, the study universe is divided into 3 layers on the basis of school type. The sample of study consists of 367 high school students studying in Mesleki ve Teknik Anatolian High School (123), Anadolu High School (105) and Sosyal Bilimler High School (139). Students answered the Curiosity and Discovery Scale and the Mindfulness Scale. First of all, relationships between variables were examined. At the same time, it was examined whether students' inquisitiveness tendencies differ significantly according to their mindfulness and gender, school type and academic achievement.

It is seen that inquisitiveness level of high school students has a mean score of 20.66 regarding flexibility sub-dimension that includes 6 items $(6 \times 3=18)$. It is seen that the average of sub-dimension of accepting uncertainty, which consists of 4 items $(4 \times 3=12)$, is 12.60 . According to findings obtained according to this, means of two sub-dimensions of scale are above middle value. This situation shows that high school students have above average curiosity levels. According to results, it is thought that emotions such as accepting uncertainty, being interested in different, not being afraid of the unknown are more common in high school students than in adults. However, according to descriptive statistics on mindfulness scale, it is seen that the average $(X=40.84)$ on onedimensional scale is low.

The effect of curiosity levels on mindfulness was examined together with variables. According to results obtained, flexibility dimension of curiosity scale and level of mindfulness show a weak negative relationship among women in terms of gender. This may be due to the negative reflections of female students' emotion and thought regulation skills, which are one of the building blocks of mindfulness, during adolescence. In male students, it was observed that there was a weak positive correlation in acceptance dimension of curiosity scale.

In the research conducted, it is seen that there is a positive relationship between curiosity and discovery levels of high school students and their level of mindfulness in the 11th graders in a positive direction. In addition, it was determined that there is a positive and significant relati- 
onship between curiosity scale and the level of mindfulness on basis of school type. It is seen that this relationship is positively significant in the level of mindfulness of Mesleki ve Teknik Anatolian High School students and flexibility dimension of curiosity scale. This may be due to the fact that Mesleki ve Teknik High School students are suitable for learning by exploring in workshop lessons. Because Mesleki ve Teknik High School students learn mostly through research, trial and error method. At the same time, there is a weak positive relationship with mindfulness scale, which is one-dimensional on basis of school type, in total of curiosity scale. However, the level of correlation between these two scales was lower than expected. In other words, it would not be correct to say that the mindfulness of students with a high level of curiosity is also very high. This situation showed that the phenomena of curiosity and mindfulness are not as related to each other as expected. However, according to the results of the analysis, it was determined that there was no correlation between the two scales in terms of academic achievement. In other words, there is no significant relationship between the curiosity and discovery levels of the students with high grade point average and their level of mindfulness.

In research, it is seen that there is a significant difference between the level of inquisitiveness of high school students and their mean scores of mindfulness, $(F=3,784 \mathrm{p}<0.05)$. This shows that students' level of inquisitiveness has a significant effect on mindfulness. However, the curiosity levels of high school students do not differ significantly depending on their level of mindfulness and the common effect of gender.

According to the results of the study, it is seen that the type of school is an important factor between the level of inquisitiveness and mindfulness of high school students $(\mathrm{F}=2.922 ; \mathrm{p}<0.05)$. It has been observed that there is a significant difference in favor of the Sosyal Bilimler High School students who have the highest curiosity score average in high school students' level of mindfulness and their curiosity and discovery levels according to their school types. This situation shows that there is a positive difference in terms of curiosity and mindfulness levels of Sosyal Bilimler High School students compared to other school types. High school students' curiosity levels did not reach a significant difference on their academic achievement and mindfulness levels. In study, it is seen 
that the significant difference between high school students 'inquisitiveness tendencies and mindfulness does not have an effect on students' gender and academic achievement.

\section{Kaynakça/References}

Acun, N., Kapıkıran, Ş. ve Kabasakal, Z. (2013). Merak ve Keşfetme Ölçeği II: Açımlayıcı ve doğrulayıcı faktör analizleri ve güvenirlik çalışması. Türk Psikoloji Yazıları, 16(31), 74-85.

A $\breve{g}$, C. ve Bağcl, O. (2018). Psikolojik örgütsel sermayenin merak ve keşfetme ile ilişkisi: Bir bilişim sektörü örneği. International Social Sciences Studies Journal, 4(24), 5137-5180. http://dx.doi.org/10.26449/sssj.981

Arana, D. (2006). The practice of mindfulness meditation to alleviate the symptoms of chronic shyness and social anxiety. Yayınlanmamış doktora tezi. Institute of Transpersonal Psychology, Kaliforniya.

Arslan, M. (2008). Günümüzde montessori pedagojisi. Milli Ĕ̆itim Dergisi, 177, 65-79.

Azak, A. (2018). Hemşirelik öğrencilerinin bilinçli farkındalık düzeylerinin belirlenmesi. Hemşirelikte Eğitim ve Araştırma Dergisi, 15(3), 170-176. http://dx.doi.org/10.5222/HEAD.2018.170

Baysal, N. ve Demirbaş, B. (2012). Sınıf öğretmenliği adaylarının bilinçli farkındalıkları ile yansıtıcı düşünme eğilimleri arasındaki ilişkinin incelenmesi. Ĕ̆itim ve Öğretim Araştırmaları Dergisi, 1(4), 12-20.

Brown K.W. and Ryan, R.M. (2003). The benefits of being present, mindfulness and its role in psychological well-being. Journal of Personality and Social Psychology, 84(4), 822-848.

Büyüköztürk, Ş. (2019). Sosyal bilimler için veri analizi el kitabı. Ankara: Pegem Akademi Yayıncilık.

Çatak, P. D. ve Ögel, K. (2010). Farkındalık temelli terapiler ve terapötik süreçler. Klinik Psikiyatri, 13, 85-91.

Çelik, E. ve Topçuoğlu, P.(2017). Proaktif kişiliğin öznel zindelik ile merak arasındaki ilişkide aracılık etkisi. Abant İzzet Baysal Üniversitesi Eğitim Fakültesi Dergisi, 17(3), 1221-1240.

Darancık, Y. (2018). Merak duygusu ile etkili yabancı dil öğretimi. Turkish Studies, 13(4), 421-437. http://dx.doi.org/10.7827/TurkishStudies.13084 
Demir, V. (2014). Bilinçli farkındalı temeli hazırlanan eğitim programının bireylerin depresyon ve stres düzeyleri üzerine etkisi (Yayımlanmamış yüksek lisans tezi). İstanbul Arel Üniversitesi, Sosyal Bilimler Enstitüsü, İstanbul.

Demir, V. (2017). Bilinçli farkındalık temelli bilişsel terapi programını üniversite öğrencilerinin kaygı düzeylerine etkisi. Uluslararası Toplum Araştırma Dergisi, 7(12), 98-118.

Deringöl, Y., Yaman, Y., Özsarı, İ. ve Gülten, D. Ç. (2010). İlköğretim öğretmen adaylarının meraklılık düzeylerinin incelenmesi. International Conference on New Trends in Education and Their Implications, 11-13 November, Antalya, $492-497$.

Germer, C. K., Siegel, R. D. and Fulton, P. R. (2005). Mindfulness and psychotherapy. NY: Guilford Press.

Gündüz, H. (2016). Yetişkinlerde bilinçli farkındalık (mindfulness) ve duygu düzenleme arasındaki ilişki (Yayımlanmamış yüksek lisans tezi). Nişantaşı Üniversitesi, İstanbul.

Hocaoğlu, N. ve Baysal, E. A.( 2019). Bilimsel araştırma yöntemleri. G.Ocak (Ed.), Nicel Araştırma Modelleri-Desenleri içinde (s.66-113). Ankara: Pegem Akademi Yayıncilık.

Karabacak, A. ve Demir, M. (2017). Özerklik, bağlanma stilleri, bilinçli farkındalık ve duygu düzenleme arasındaki ilişkilerin incelenmesi. Bayburt Ĕ̆itim Fakültesi Dergisi, 12(23), 271-291.

Karasar, N. (1999). Bilimsel araştırma yöntemi kavramlar, ilkeler, teknikler. Ankara: Nobel Yayın Dağıtım.

Kaya, G. İ.(2016). Eğitimde merak ve ilgi. Hasan Ali Yücel Eğitim Fakültesi Dergisi,13(25), 103-114.

Langenscheidt.(2019). Güncel Sözlük. Erişim: https://tr.langenscheidt.com/

Langer, Á., Schmidt C., Mayol R., Díaz, M., Lecaros J., Krogh E., Pardow A., Vergara C., Vergara G., Pérez-Herrera B., Villar M., Maturana A. and Gaspar P. (2017). The effect of a mindfulness-based intervention in cognitive functions and psychological well-being applied as an early intervention in schizophrenia and high-risk mental state in a chilean sample. Study Protocol For A Randomized Controlled Trials, 18(1), 233-243. http://dx.doi.org/10.1186/s13063-017-1967-7.

Ludwig, H. (2015). Praxishandbuch der montessori-methode. Verlag Herder: Ger-

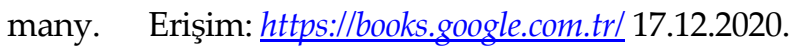


Özen, Y. ve Gül, A. (2007) Sosyal ve eğitim bilimleri araştırmalarında evren örneklem sorunu. Atatürk Üniversitesi Kazım Karabekir Eğitim Fakültesi Dergisi, 15, $394-422$.

Özer, B. ve Korkmaz, C. (2016) Yabancı dil öğretiminde öğrenci başarısını etkileyen unsurlar. Ekev Akademi Dergisi, 20(67), 59-84.

Özyeşil, Z. (2011). Üniversite öğrencilerinin öz-anlayıs düzeylerinin bilinçli farkındalı, kişilik özellikleri ve bazı değişkenler açısından incelenmesi (Yayımlanmamış doktora tezi). Selçuk Üniversitesi, Eğitim Bilimleri Enstitüsü, Konya.

Özyeşil, Z., Arslan, C., Kesici, Ş. ve Deniz, M. E. (2011). Bilinçli farkındalık ölçeğini Türkçeye uyarlama çalışması. Eğitim ve Bilim, 36(160), 226-227.

Sekreter, S. ve Akyüz, G. (2003). Pazarlama araştırmalarında kullanılan ölçeklere ilişkin bir yayın taraması. Akdeniz Üniversitesi IÏBF Dergisi, 6, 123-150.

Soydan, S. (2013). Çocuklarda merak duygusunu uyandırmada montessori öğretmenlerinin kullandıkları stratejiler. Mehmet Akif Ersoy Üniversitesi Eğitim Fakültesi Dergisi, 25, 269 - 290.

Şahin, A. (2019). Üniversite öğrencilerinde bilinçli farkındalık ile yaşam doyumu ve iyi oluş arasındaki ilişkiler, Üsküdar Üniversitesi Sosyal Bilimler Dergisi, 8, 151-176. http://dx.doi.org/10.32739/uskudarsbd.5.8.61.

Şahin, Ç. ve Karakuş, G. (2019). Bilimsel araştırma yöntemleri. G.Ocak (Ed.). Katıllmoları Seçme: Evren ve Örneklem içinde (s.187). Ankara: Pegem Akademi Yayıncilik.

TDK. (2019). Güncel Sözlük. Erişim: http://tdk.gov.tr/ 17.01.2021.

Tezbaşaran, A. (1997). Likert tipi ölçek geliştirme kılavuzu. İkinci baskı, Ankara: Türk Psikologlar Derneği Yayını.

Ülev, E. (2014). Üniversite öğrencilerinde bilinçli farkındalık düzeyi ile stresle başa çıkma tarzının depresyon, kaygı ve stres belirtileriyle ilişkisi (Yayımlanmamış yüksek lisans tezi). Hacettepe Üniversitesi, Sosyal Bilimler Enstitüsü, Ankara.

\section{Kaynakça Bilgisi/Citation Information}

Ocak, G., Akkaş Baysal, E. ve Yer, U. (2021). Lise öğrencilerinin merak düzeyleri ile bilinçli farkındalık düzeyleri arasındaki ilişkinin incelenmesi. OPUS- Uluslararası Toplum Araştırmaları Dergisi, 18(42), 5577-5609. DOI:10.26466//opus.919627. 